$\leadsto$ Wow $\times$ to $\times$ Wanage

Agribultural $\times$ Wairs $\times$ Reres 


\section{LIBRARY OF CONGRESS,}

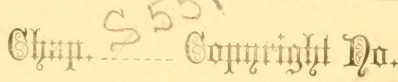

$$
\text { Shelf : } 428
$$

UNITED STATES OF AMERICA. 




\section{HOW TO MANAGE}

Agricultural Fairs, Industrial Institutes, and Similar Exhibitions.

\section{A COMPLETE GUIDE}

$-\mathrm{FOR}-$

\section{DIRECTORS, SECRETARIES, AND OFFICERS,}

\section{-CONTAINING-}

Directions for their organization, applicable to every kind of society and joint stock association; rules for the selection and laying out of grounds, building tracks, the omamentation of buildings, halls, ete., and choice plans of administration.

\section{SELECTED FROM A STUDY}

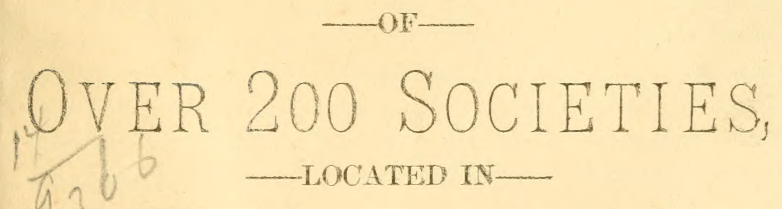

DIFFERENT STATES.

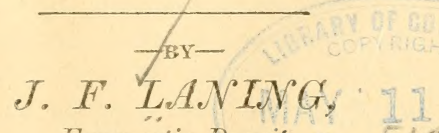
Experentia Docuit. No... 506

NEW LONDON, $\sigma^{\circ}$

THE FAIR PRINTING COMPANÝ,

1881. 
Entered according to Act of Congress in the year 1881, by J. F. LANING, in office of Librarian of Congress, at Washington, D. C. 


\section{PREFACE.}

It is needless to say that the author in examining the workings of different societies has found a great amount of crudeness among them. How to manage a Fair successfully is a desirable attainment. Their management may be said to be the measure of their success and will account for the fact that some are live, attractive, and prosperous, and others feeble, uninviting, and inactive.

The fact is often overlooked that a Fair is a business institution requiring capacity to manage it, as do other institutions, and that it is one of magnitude, dealing in different relations with many people, where experience, skill, attention, and regularly defined methods are highly essential to harmony and success.

There has been too little progression in our Fairs. The idea that most anyone could manage a Fair has put them in the hands of incompetent men, who have neither ability or energy enough to originate or adopt new ideas, and hence many of our societies present a picture of sameness at their Fairs every year instead of giving them a bright, fresh, and attractive look that will make them inviting.

The key that will unlock the mystery of the decay of some Fairs will be found in the fact that they have been run too much for the present and too little for the future. The American people love recreation, and our Fairs are popular with them, but they are both sensative and sensible, and to hold their patronage anywhere they must be well treated.

The author of this work has been for years connected with one of the most successful Fairs in Ohio. To gain the knowledge for this work he has visited and had correspondence with several hundred societies, and in drawing conclusions from their workings has made a number of important discoveries, and has been able to make many suggestions of a practical nature.

The work is intended to supply all, and especially the inexperienced, with a correct knowledge and a clear un- 
derstanding of the rules by which the business of agricultural societies and other similar associations should be administered. It treats of the subject from every point of view, and enters largely into details. It will aid officers, managers, superintendents, and committees in discharging their duties, and it is hoped will build up a uniformly high standard of integrity and suceess among these institutions.

But few societies exist whose management is not susceptible of improvement in some particular. The work is therefore commended to all, feeling that to each it will be important, and to many valuable, both in learning what others are doing and promoting their own welfare. 


\section{CHAPTER I.}

CREATHX AND URGANIZATIOX OF CORPORATIOXS, JUTY STOCÍ ASSOCIATIONS, SOCIE'TLE, E'TC.

Sicrion 1. Statutory Regulations.-In most states statutes exist regulating the croation of (e)ponations. Associations, and societres, such as of which we treat, and defining the powers, privileges and immunities conferred upon tirem. These are easily accessible to all inter. ested parties, and are beyond the seope of our work, which is intended to deal with methods of conducting them. rather than theip legal rights and ohligations. These statutes are, however, the coustitutional haw by which authority is conferred upon them, and to secure the rights and immunities they wam, as to the presceiber methods of organization, should be complied with, lest they otherwise be iost.

SEC. 2. Urganization and Constitution.-When an organization is determined upon, it is usual to have, aud the laws of some states requir, a meeting at some previo ously appointed time aud place, to adopt plans and define the limits within which the business is to be conducted. This, when made out and reduced to writing, is called the Constitution of the society, as we shall use the word to designate all bodies of this character, and suliject to statutory limitations with which it must not conflict, it 


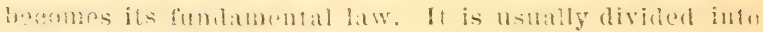
fections, and, uness given by statute. provides or defines the following thongs: A name for the society; the olyect for. which it is organized; the place where it will transact business; the amounc of its capital stock, if it have one, and how divided; the quaticutons of its members; its management; how its amenlment or alteration may be

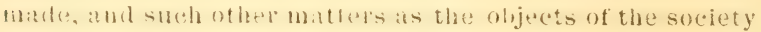
require. These we shall nolice in turn.

SEc. 3. Name of Society.-Names are varous, de. pending mon the business transacted and the tastes of the mombers. They anderally refer to the location of the fociety and detine its charater. That chass more par.

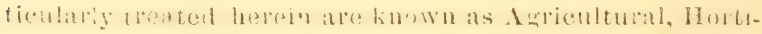

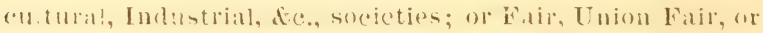
Independent Fair Associations, Expositions, de.

Sirc. 4. Objects.-of course the statement ot ohjects depend upon what they are. In this class of someties

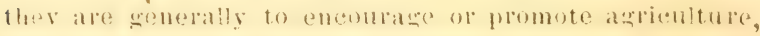

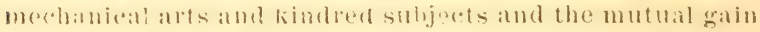
of the members. Sometimes the statutes define the ol, jects, in which catse they should he substantially followed.

SEc. J. Locatrou.-This should be detined so as to avoid any uncertainty.

SEu t. Capira stock.--When a company has a capte$t$ 1l stock, the ammunt should be stited, and the number and size of the shares griven.

SwC. 7. Membership.-This wili depend upon t!e plan dipon which an organization is to be eflected. Shousd it be a joint-stock company each stockholder will be a member, and it will bo necessitly to provide for the issue of cer. tificates and their transfer trom one person to another. 'liney are ustrally required to be signed by some of the ofticers, as the l'resident and secretary, and their transfer required to be in writing, upon the back thereof, and not to be valid until entered upon the books of the company. 


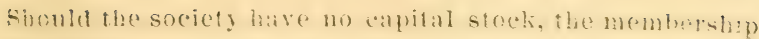
is refined to consist of those who pay a certain sum into

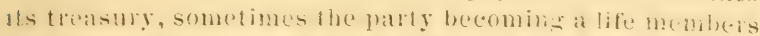

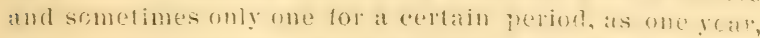

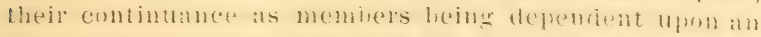

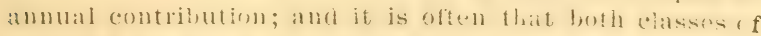

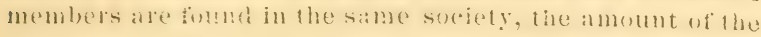
fee being difleront. In some instances the society is a county or disirict one, so that the electors contuiluting in a certain region are members.

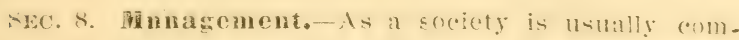
posed of many persons, a meeting of all of them for the

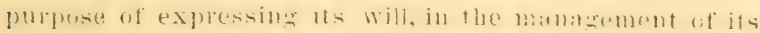

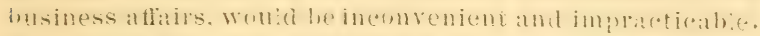

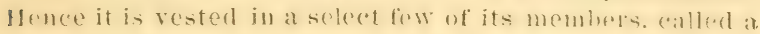
Board of Managers, Directors, or 'Trustees. 'To gruard axainst incomplency of abuse of power, they are selected, wholly or partially, each year, and it is usurito provude that they shall serve for a certain period, and until their successors are elected and qualified. Care should be taken not to make this hody too latge, as its action will often he retarded and a quorum often found wanting when husiness is to he transacerel. When the afiairs of a socety are peculial to a certam district or

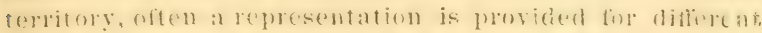
yarts orit, as each township in a county. When the man-

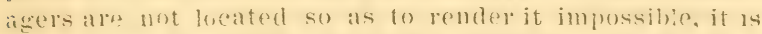
fouma comvenit nt to have their number some malliple of their term of othee, so that an equal number of them shall retire each year. In general it mat be said that, moless restricted, this Board will prosess all the powkls mbich the society weuld have if they ind no mamagers, and such purers as are necessary for an ecomomical and suceeseful yrosecoutron of the purposes of the society. It is tiie angut, of the mombers, and its acts, within the scope ot theob. juets of the society, will be hinding. It is msual, homeser, to define the nmmber of the managers that shall constitute a. quurum (usually a majority), and provide that it sinal) bave power to appoint such agents and committeeg as 
are deemed proper to cary on the business of the socsety, and to pass the hy-laws necessary to carry out in detail the nowers conferred upon it.

swe. 9. Management, continued-Officers. - The asual oflicers are a President, Vice President, Secretary, and Treasurer, and their term of oftice one year and until their successors are elected and qualitied.

\section{SEC. 10. Election of Directors and Officers.-A time} is usually set upon which annually a meeting of the members of the socrety shall be held at its place of business, for the election of managers and the transaction of such other business as may come betore it, at which, if it is a joint-stock association, earh member may cast as many protes as he may have sliares of stock in person or by moxy; if otherwise, each member may cast one vote, and a majority of the votes cast shall be necessary to elect. Vacancies in the Board of Managers arising from any sause, are usually left to the remaining members to fill nutil the next annual electron, though sometimes they are reruired to be filled ty a ealled meeting of the stocklolders. When competition oceurs elections are by bal. tot. The selection of oflicers is sometimes made hy the stockholders, and are outsile of the board; but it is usual to require the board to meet within a short period after the annul meeting, and elect from their number a President and Vice President, and a Secretary and 'Treasurer, from any persons having the requisite qualifications.

SwC. 11. Duties of Oflicers.--The executive office of the society is the Presidency. 'The P'resident is required to preside at the meetings of the board; has general super. vision and custody of the atlitirs of the society, and sees that its laws are enforeed; is required to sign all money orders on the treasury, and call meetings of the stockholders, when business arises which is necessary to bo submitted to them.

The Vice President acts in the absence of the Prssident, and assists him in the prosecution of his duties. 
The Secretary is the clerical oflicer of the society, conducting its correspondence; keeping a record of the proceedings of the society and Board of Managers; drawing orders on the Treasurer for money; making annual reports of the society's condition and doings, and generally performing the work of the society of a clerical nature. IIe is sometimes required to receive all money of the society, and pay the same over to the Treasurer, keeping an account of the sources from which received, instead of having it paid directly to the 'Treasurer. For a discussion of this matter see chapter ix., on accounts.

The Treasurer receives the money of the society and pays it out on the proper order, and reports annually the amount received and disbursed by him. 'The smount of oflicial bonds is sometimes prescribed, though more often left to the Board. 'The Secretary and Treasurer are usually given a salary for their labors, to be provided in the by-laws.

Sxc. 12. Amendments and Alterations.--The amenclment or alteration of the Constitution is usually limited to the annual meetings, though it is often provided for being done at called meetings. Notice of the proposed change, by publication or otherwise, is requred, however, in order that each member may have time to consider it, and be prepared to act intelligently. Two-thirds or three-fourths of the votes cast are often made necessary tor the purpose.

Sec. 13. Enactment of Constitution.--In the enactment of a ronstitution at the first meeting of the associa. tion, it is usual to appomt a committee to prepare a draft and report at a future meeting, a tew days later; where. upon the meeing adjourns until the day named. Sometimes, however, a drait is prepared beforehand, ready to present at the first meeting for adoption. Whenever it is presented, it should be read from beginning to end, to enable everyone to become familiar with it, and sec the bearing and connection or the different parts and their 
relation to the whole. Having been thus read, it is taken up and alopted section by sectuon and articie by article.

siec. 14. Fodel for a Constutution.--The following, through wot complete, Whll serve as a suide for farties dratting a Constitution:

ArTICLE 1. This soerety shall be known as-_- .

AnT. 2. Its oljects shall be - _-_-

Ant. 3. The business of the society shall be carried on at

Ar'T. 4. Its capital stock shall be \$_, diviled into - shares of $\$-$ each.

ArT. 5. 'The members of the society shall be such as are the owners of one or more of the shares of its calyilal stock; or any person may becume a member of the society tor the period of one year ly paying the sum of $\$$-.. into its treasury.

ART. 6. 'The control and manacement of the society shall be vested in a Board of - Directors. Whose form of othee shall be - yeal's each and until their successors are chosen and qualified. They shall have power 10 appoint such agents and commitees and pass such by-laws as may become necessary to carry on the husiness of the society. (Add other aesired powers and restrictions.)

ArT. 7. The oflicers of the society strall consist of President, Vice Presilfut. Secretary, and 'i'reastrer, whose

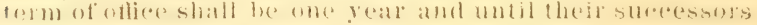
are chosen and qualitied.

Art. s. The Directors unw elected shall serve until the - day of nexi, at which timie, and annually thereafter, the Darectors shall be elected to serve for one year; or there shall be - - Directors elected to serve fin ore year, — for two years. \&c., and ammaliy thereatterDirectors shall he chosen for (the term of their nilice.) The election shall he comrinceted hy hallot, and a maj'ing of all the votes cast shall tie necessary to elect. On or before the -____- thereafter the Board shall comvene athd choose from lbeir number the fresibent and Viees President, and selecet a sultable person bor secretary and Treasurer.

Art. 9. The President shall presile at all meetiners of the Board, die.

ArT. 10. The Vice Presilent shall perform the dufies of the President during his absence, de. 
A RT. 11. The Socrotaly shall attend all moetings of the

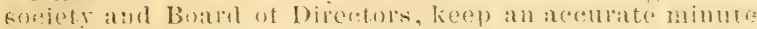

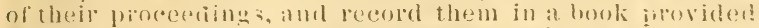
fir the purpose; conduct the correspondenre of the so. (eirty, fr.., and receive such compensatiun as the board shall provide.

Arr. 12. The Treasurer shall keep an acemate acenmut of the money of the soreiety receivert amol paid olat by hila; he shall wive bond. with gond and suffeicent secorrity. in silch at sum as may be required by the Buard of Directors, \&e.

A IRT. 12. No alfilation, by amendmont or otherwas. shall be made o this (ionstitution exeept at an ammual meeting of the suciety, on a called meetine for the put:pose, at least ___ werks' notıce thereof having been previonsly griven by publication in - - of hy tiling a resnlution for tue proposed rohage with the Sicretary: and a - votesh ill be reguirea for its adopion, $\mathcal{E}$. ve. 


\section{CHAP'TER II.}

BOARD ILETINGS, BY-LAWS, NTC.

SEC. 15. Official Acton.--Throurh the Board of Directors the society acts, and the only rioht which is usually enjoyer! by the members at large is to amulally expless their will as to who shall represent them, and as to the policy of the society in electing such as will execute their will.

Sec. 16. By-Laws.--Incident to the rights of this body. thomgh usually found 11 its organic law, is its right of making iy-laws for its own grovermment, and providing the details as to the execution of the powers conferred upon 1t. Sometimes these will be limited to some extent by the constitution, but they are usually left to the dis. cretion of the Board under a natural and implied restriction that they must not be repugnant to the objects of the society, the laws of the land, nor in excess of its powers. The subjects they usually embrace are as follows: i, Board meetings; 2, order of business; 3, voting; 4, ap. pointments; 5 , official bonds; 6 , amendments; 7 , records and accounts, fre. These we will consider briefly.

SEC. 17. Board Meetings.--'The meetings of the Board, where business requres it, are set for regularly recurring dates. Unless so set, they occur on days to which they 
have been formerly adjourned, or upon which they have been called. special meetings are usually upon the call of the President or two members of the Board; and sometimes when regular meetings are had, for special meetings a notice in withe to each member, stating the object of the meeting, is required, and the provision male that no other business sliall be transacted at the meeting, unless all the members are present.

SEC. 18. Oriter of Husiness.--The rules for enductind the proceedings of the Bond usually provite for an order of business as follows, yiz:

1. Calling the roll of members.

2. Iisaling the minutes of the previous meeting.

3. I'resentation of bils and reference to rommittees.

4. Reports of oflicers and committees.

5. General business.

Writh this it is usual to provide that the dediberations of the board shall we conducted according to the ordinary aules of parlamentary law.

Spc. 19. Voting.-In the elertion of nflicers and in se. lecting members of committees, dec., the By-Laws uswally requme that when more than one candudate alpears the Fote shali be taken by hallot, and in other eases viva voce. In cases of strong competition an informal ballot is often talen to reveal the strengli of the several candidates. Gometimes provision is mate for a yea and nay vote, by furing the roll called. to which every member restonds and his vote is recorded.

SEC. 9). Apposintment of Commitrees, \&c...Then the work whll armit of sub-divisions, and often when special matters oceur, it will be found convenient to eommit them to one or more persons to talie charge of or investigate. Care should be exercised to avoid making conmit. tees so barge as to be unwieldy, and the fitness of the members for the purposes sought shonld also be regarded in selecting them. Committees are of two kinds, standing and special. When not otherwise provided for, the power 
to appoint them is given to the l'resident, and uness some reason exists agalist it, the mover for a committee is made its chatrman. The matters that may he committed are varous. 'The principal committees and their duties are nablly designated in the By-Laws. Intorma-

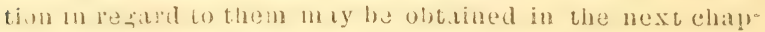
ter, deroted to commiltees.

SEc. 21. Olieial Bands.-When the Constitution leaves the amountiof these to be regulated by the Board, they sinould tix it with regard to the funds that will comes into the oflicer's' itaturls.

SEC. 2.- Records and Accounts.-. Sometimes a by. Iaw is made designationg what hooks and aceounts shall he kept and reports required, and hy what ofticers; such as, a regioter of stockhoblers of members; a record of the min-

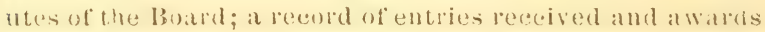
made, a report of which is offen required to be published; a werneral aceount of the receipts and expenditures of the Society, elassified in lunds, accorling to the nature of each, de.

SEc. 23. Salaries. - When the Constitution does not, provide ofluerwise, the salary of oflicials should be fixed in the By-Laws.

Swe. 2t. Amendments.-Provisions similar to those in Sec. 12 are usually inserted in the By-Laws.

SEC. 25. Rodel for $\mathbf{B y}-\mathbf{l}$ aws. - The following, thollot not complete, will serve for a guide for parties dratting By-Laws:

ArT. 1. 'The regalar meetings of the Board of Directors shall oceur on the - of each _ at - o'clock - M. Special meetiligs may be called at any time.

ArT. 2. The deliberations of the Board shall be enn. ducted arecording to the ordinary rules of parliamentary law. 'The following order of proceeding shall ba observeds viz:

1. Calling the roll of members.

2. Reading the minutes, dic. 
ART. 3. When the name of more than one person is presented for any appointment or oflice, the vinte siall be taken by ballot; all other votes shall be taken viva voese
dec.

ArT. 4. Unless ntherwise provided all eommittees shail be appointed by the P'resident, and shall consist of memivers each.

Are. 5. 'The following standing eommittees, viz.. Fxecutive Commitfe, Aniting Commitlee. de.. shall he appointed ammually at the sirst meeting of the Board after its organization.

ArT. 6. The duty of - Commitee shall he-(areseribing it and that of each of the remaining committees in turn). See next chapter.

AnT. 7. The following special enmmitfees, viz., (naming them) shall be appointed whenever their creation is advisable.

ART. 8. The duty of the Committre on - shall he, for, riescribing it and the ethers as above. (See next chapter.)

ART. 9. The bonds of the Treasurer shall be $\$-$.

ART. 10. The Seceretary shall keep an aceurate aceount, showing all the moner, ofe. If shall have charee of making the entries at the ammanl exhibition of the society, and shall cause to be buhlished a report of the arwals made thereat in the w whin three weeks thereatter.

'The Treasurer shall keep, der.

ArT. 11. The nfficial salaries of the officers of the Snciety shall be as follows, viz.

Art. 12. These By-latws may be altered by a majority
te, \&c. 


\section{CHAP'IER III.}

\section{COMMITINES.}

SEe. 26. Necessity of Committees.- When the numb. of persons to whom the execution of any matter is enfrusical is large, the fendenoy is for eateh to rely upon its being attended to by ofhers. and hence it becomes ney lected. One of a small mumber of persous will, as a rule. investigate a matter more closely or attena to it more surely than a laree number. Hence, it is usual to entrust those matters that will arbit of it to a select few (thoe is the ustall ummber), with atuthority to investimate or act in the matter, either controlling it fully or reporting their conclusions to the Board, who ratify or reject them. These are termed committees, and they are standing or speratal aceroling to the permanent or transient character of the matter to be entrusted to them. The person first named on a committee acts as its chairman, and calls the committee together and presides at its meetmgs. The secretary, upun whom the Board tnrust many duties to escape themselves, will fully appreciate the value of committees. It is olten that a few willing ones are obiged to do all the work in such an enterprise, but it should not be nllowed, as otherwise, although the success may not be more decisive, yet it may be more harmonious. 
Sic. 27. Standing Commutees.-The experience of difierent societies hias shown the neressity of having cer. tain permanent or standing committees, to which matters that are constantly arismg can be readily referrec. 'Two of these are the Executive and the Auditing Committee.

The Executre Commrtee is entrusted with arranging the detals and carryng out the measures adopted by the Board. It usually consists of the officers of the Society and one or more directors. Somelimes it is given power to act in the ahsence of the Board, or when impracticable to convene it, upon all matters which arise de manding immedate altention and their action is made binaing upon the Society.

To Trx Auding Commotes is referred all bills and chaims against the society and the reports of its oficers, and they are required to examne them and report as to their correctness as soon as practicable.

The wauts of difierent societies will suggest other standing committees.

SwC. 2S. Specia! Committees.-When any enterprise is to be undertaken, several committees whicn the nature of the business wil! prompt will he found convenient. For a Fatr each of the following topies may be profitably con. fided to separate committees, viz., Rules and Regulations, l'remiums, Printing and Advertising, Invitation and Re. ceptron, Supplies, Police, $\Lambda$ wards, and Rental Privileges.

In constituting these committees it is usually provided that certain officers of the Society shall be members of certain committees, as the President a member of the Committee on Invitation and Reception, the Secretary a member of the 'ommittee on Rules, \&c. They should be reruired to perfirm their duties and have their reporte ready, so as not to cause any delay.

SEC. 29. Duties of Committees.-The duties of these committees will be as follows: 
The Committee on Rules and lusgulations is perhaps the most important one to be selected. 'To it will be entrusted the preparation of plans and drafting of rules and resulations, detining the mole of conducting the exhibibition. Its members should be men of good pereeption, wide awake, and eapable of detecting any errors that may sxist in the establinhed methods of the society, and improving them as experience and groud judgment justifies. A Society to suceeed well must he progressive. Care, nowever, should ie taken to obtain practical rather than theoretical mon. The duties of this eommittee are some. times put in charge of a Committee en Ways and Means.

The Committee on Preminms is also an important one. To them the items upon which premiums are to be oflered, and the amount to he paid upon them, are entrusteá. In many (lepartments changes are comstantly going on, and, tor he progressive, additions to the list will be required each year. 'To be attractive an exhibition must be up sith the times. A few prominent teatures often are the means of producing an interest that is highly valuable to the society. 'Therefore, the committee should be eom. posed of men who are able to flesignate a list of articles and contests that will he athactive enough to draw a profitable number of spectators to the Fair, and who will have judgment suflicient to keep the amount of money to be paid as premiums where it will not he rumous to the Society, from bengr either too high or too low.

To the Committee on Printing and Advertsing is civen the matter of securing the printme of such matters of the Society as are for print, and of arlvertising its exhibitions. They usually oblain a list of what is wanted from the proper sotires, and contract with some person, in behalf of the society, for furnishing it. They often have charge of originating the mater and modes of advertising, thungh the former is usually left to the Secretary or some person employed for the purpose.

To the Committee on Invitation and Recention is en- 
trusted the sclection, leception and care of invited gursis Its members should be selected with regard to their natural courtesy, politeness, and ability to entertain.

The Committe on Supplies has in charge the matter of providing such artic!es as are usually needed to suyply the wants of parties attending the exhibition, such as foot for stock, straw for vedding, \&ce

The Committee on Pulice emplnys and has eharge of the police force.

The Committee on Awaids has the selection of the vari. ous awarling committees. Sometimes they are requiaed also to select the Superintendents of Departments. They should sit during the Fau, so as to fill any vacancy that may arise in committees.

The Committee on Rental Privileges has charge of the lething and selling of the respective stands, brotns and privileges which are usual upon the grounds.

Other committees, such as Transportation, ilusic, Ec. are sometimes provided for. 


\section{CHAPTWR IV.}

\section{GROUNDS AND BUILPINGS.}

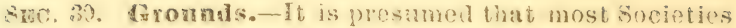
have frounds; but, if one have not, when an exhibition is determinet upon, it will become important to provide is suitable place for bolding it. It is not expectea that any oin be found which will haye all the goor fualities that *an be enumerated, but eare shoukl be laken to eombine as many of them as possible. The selertion shonlat be male with a view to natural eonvenience and attractive ness. It should be high enowgh to be dry; rollins enough 4, avoid stambing water after a shower; with plenty of shade and where an abundance of water ean be obtaned. Whe ralue of shade and water cannot be oyer-estimated, as mothing letracts more from the siaceess of a trip to a fair (esually planued for a day of rercation and pleasure) hur to be compelled to stand in the unobstructed rays ot the hot sun all day, with mo water to quench the thirat whici the heat engenders. People so treated onec sever attend the second time.

The site for the grounds, anless apcoin fincilities exist for reaching it, should be near enough to the village where located to be easily aceessible. 
The size of the grounds will depend upon the extent of the exhibition. It should, however, be commodious, and enclosed by a tence sufticient to keep out intruders who seek to enter it clandestinely. This is usually from six to seven teet high, sometimes built tight; but the best method, except when a tight fence may be required, is found to be the use of pickets about four inches wide, leaving a space of the same width between each. Such a fence will btand storms of wind better and be more durable than a tight tence.

SEc. 31. The IRing.-Without here discussing the ques. tion of racing and its morai bearings, we say that it is usual to lay out a ring of some character, to exercise and speed horses upon. Its size depends upon the ground that can be devoted to it, though it is seldom less than one-third of a mile in circumference: as when smaller, horses cannot accomplish the short turus it must possess, at any high rate of speed. Usually it is either a mile or a one-hall mile track. It is generally composed of two par. allel straight sides, called stretches, having their ends joined by perfect semi-circles, called the turns. The home stretch is the one where the tinish is made. Upon it, lo. cated on the inside, 60 yards before entering the turn, is placel the Judges' stand, and below it are placed, at re. quired points, posts called distance posts, for determunng when horses are distanced. The turns should be graded like the track of a railroad or circus, the outer portion the highest, so that a horse can extend himself at ful speed as well around the turns as upon the straight sides. The width of tracks vary from 25 feet upwards, and usually the first turn is much the widest. The line of measurement for a track is three feet from the inside or pole. A practical engineer with a transit can locate perfectly a track of any required dimensions over any ground, and establish good grades for it; but for those who cannot well obtain an engineer, we give some rules for laying out some of the simpler tracks.

SEc. 32. Layıng Out a Track.-First ascertain how long the grounds to be used will admit the sides of the 
track being made. If a mile track is to be constructed, sulitract the sum of the lengths of the silles in feet fiom 5.2S0. If a half mile, from 2.640 ; divide the remaindter by 3.1416 ; subtract 6 from the quotient, and the remainder will be the width in feet which the sides may he placed apart. Place a stake midway between the ends of the silles; take a wire with a loop at the end loose enourh to turn the stake, and measure upon it one-halt of the aistance hetween the ends, and with it describe a semi-circle. berinning at the end of one of the sides. putting down a stake to mark the course every ten or fifteen fret. 'This line will be the inside of the track, and where the tence should be placed.

The following a:e some of the dimensions required for certain tracks:

A mile track, with the sides 1320 feet long, will require them to be 841 feet apart, and contaiu 46 acies.

A half-mile track with the parallel sides each 600 feet Jong will have its sides 452 feet $43 / 8$ inches apart, and require about 12 acres of ground.

Ilalt mile tracks may also be constructed of the following dimensions:

1. Take a piece of ground 210 yards square; measure off a square of 6:98 feet; cut ofl the four cormers with at une. fourth cucle of 99 reet radius. The stretches will be 500 teet each. 'T'wo of the sides may be lengthened withont regard to the turns, and the other two diminished accord. ingly.

2. Take a piece of ground 400 yards long and 125 yarls wide; measure ofl two straight sides, 800 feet long, and make the ends with a radius of $1621 / 2$ teet. 'This will make a track 25 leet wide.

3. Upon the same ground as the last, a wedge-sbaped track may be laid out, by making the cirsle at the large 
end with a radius of 225 feet and at the smaller end with onc of 100 feet, joining these with straight sides 800 teet long.

Besides this, a small ring is sometimes thrown up for the purpuse of exhbiting stock mon, and is found very useiul.

Sxc. 33. Buildings.--We cannot here give details and plans for erecting bundung, and shall only attempt to give the different classes that are used and a few general remarks concerning them, leaving the details and specifica. tions to be taken care of by the architects employed in their construction. Iferefofore, societies have generally erected independent huiluings or halls tor each of the de. partments represented at their Fair; as a Mechanics Hall, for manufictures and small machinery a Floral Hall, for vextile tabries, flowers, plants and fine arts, thourh each of these $\mathrm{i} .3$ sometimes separated; an Agricultural and IIorticultural IIall; and sometimes a Merchants' Hall, a Music Hall. dic. Of late, however, there is a tendency to confine these departments. except for mechanical inventions requiring power to nove them, to one buildung. assigning a portion of its space to each and it is tound to heighten the appearance of the exhibition and give better satisfaction to exhibiturs in the display of their goods.

Above all things, whetever buildings are built, let them be commodious, with good height between the floor and roof, and with good openungs, so that visitors can readily pass $m$ and out, and plenty of air and light can be obtainec. They should also be tastily erected, so to ornament the grounds if possible. The boards for sirling should be planed and painted, as without it when they become old they have a dismal appearance. Some societies attempt whitwashing old buildings; but it. rubs off easily, becomes colorerl and looks so cheap that it is foubted whether anything is gained by it. Good bildings will readily pay for themselves from the increased attendauce they attract to the Fair. 
For live stock accommodations are also provided. They consist of stalls, pens and sheds, covered so as to protect their occupants from sun and storms. They are built from rough boards, and whtewasi nere adds to their neatness and sweetness. For the more valuable elasses of stock, where they are liable to become lamaged rom rain, the roof should bo shingled, as a common board one ran soldom be made tight enough to shed water for any length of time.

A hay and graln barn, sometimes but a building conlaining a covering and sides extending high enough to keep people trom climbing into it, and open at the top, is uneful, and will pay for itself in a few years srom the saving it makes.

Ampitheatres upon exhibition grounds and racing iracks afford tine views of the sports, and are protitable in the way of admission fees charged to enter them, and give the Society room beneath for varous purposes.

Besides buildings for these purposes, Dining Ilalls, Booths and Stands are sometimes built by the Society, but more orten by parties renting such privileges. Band Stands and Judges' Stands are also common.

Ticket offices should be erected near the entrance to the grounds.

SwC. 34. Decorataon of Halls and Buildings.-It is usual for the Society to aftorn their balls and buildings, so that they may be atractive to visitors. It is a matter in which good taste is demanded. Too profuse ornamentaeion is regarded as an error. Among the things used for tbrs purpose may be mentioned fountarns, festoons and wreatiss of evergreens, flowers, plants, Ec.

Fountains are splencid ornaments, and can be readily supplied where there are no water-works by elevating a lwarrel on the roof of the building, with a sma!l gas pipe Resding frow it co the sountain. A cheap fonntain can be 
made by putting a small nozzle on a gas pipe, and having nn ordinary wooden bowl painted for a basin, through tho bottom of which the pipe passes.

Cut paners answer well for decorations. A fine arrangement for flowers and plants is to have them located between aisles, set in clusters or built in pyramids, with mosses and sods of earth between them. 'They may also be set to one side upon stair-like shelves to advantage. Gare should be taken to have them sufficiently protected trom vandals, whose fingers will ruinously prek and slip them, if they have an opportunity. White wall paper may be used for coverings of posts and wood work tbat it is not desired to have exposed, and some patterns make de. cidedly beautiful backgrounds, \&c. 


\section{CHAP'TER V.}

PRINTING AND ADVEIRTISING.

SEC. 35. The Premium Listo-In order that it may be known in what manner the exhibition is to be conductei and what competitinn and exhibits are desired, it is usual for the Secretary or some other person having the same in charge to make a catalosue of the rules and regulations pertaining to the exhibition, the ofticers of the suciety, superintendents of Departments. and sometimes the Awarding Committees, and such other information relative to the exhibition as may be deemed important, and have it printed in pamphlet form for distrib!tion. Sometimes it contains the Constitution of the society and a list of its members. When chcapness is aimed at, the list is often printed in newspaper torm, saving covers and binding.

Swe. 36. How to Cheapen Advertising.-To cheapen the expense of getting out this catalogue it is usual to ob. fain advertising to be inserted in it, it beng an attractive medium for business men, stock breeders, \&c., to notice their groods, and the protit on the amount that can be obtained is often sufticient to pay the whole cost.

It is usual to have esther a page of premiums and a page of advertising opposite it, or have the pages divided into fuo columns, one for advertising and one fo: premiums. A more handsome and preferable way is thought by some to print the adrertisements upon colored paper seyarate trom the premium pages, and insert four or eigbt pages of them between each fold of the book. 
From these and other advertisements that can be ob. tained, with the program of the Exhibition and other matters of interest te exhibitors and visitors, a small paper or hulletin is often orinted and distributed gratuitously ameng those in attendance at the Fair. When it can be done, it is a good plan to have this issued daily, and by adding to it a list of the awards and doings of the previous di $y$, it can be sold for one or tivo cents and made remunerative.

SnC. 37. Posters, Circulars, Etc.-Th advertise the Exhibition large posters, calling attention to the date and announcing the most attractive features, are gencrallv put up in conspicunus places. Smaller ones are used as circulars, and to take the place of the large ones in stores and business places not having sufficient ronm for their display. Small ciodgers, making a special annauncement, are sometimes passed about, and are often used to ad. vantage among a crowd that has assembled upon some occasion. A strip from tour to six inches wide, announc. ing the date of the Exhibition, as "Jones County Fair, June 17-20," is often put up upon fences and buildings at the roadside to attract, the eye of travelers. In all nurdoor advertising it is needless to say that paste should be used to put up the bills, as otherwse they will go down in the first wind or shower.

swc. 32. Chean Advertising.-cietting too cheap ad. vertising is like "saving at the spigot when there is a leak at the bung." It is said that "the apparel oft proclaims the man," and this way of judging is often applied in other respects. $\Lambda$ bedaubed and half-printed job, on poor paper, is often taken as the indication of a worthless, half-way socrety, and is passed without regard. While one made in gond style, clean and neat, will be attractive and draw mans times more to the society than enough to pay the difterence in cost. To let people know what is going to be done, it is necessary to advertise, and to draw them to the Fair it must be well and judiciously done. Great care should be taken in this regard. 


\section{CHAP'TEL V.I.}

\section{YNSTRUCTIONS IN PREPARING PREMIUM LIST.}

SwC. 39. General IRemarks.-1t has already been said that the list of premiums is one of the most important things connecter! with the Falr, and for that reason ite repetition may be excused. It must be properly gotten up, and from year to year must be so changed as to be kept in hamony with the requirements of the times.

Skc. 40. Classification.--The items upon which premiums are oflered are usually classified into Departments, which are sub-divided into such classes as they will admit. The items of a kind are thus all brought together. At the head of the Department the special rules applicable to ic are placed, and so at the head of each Class. This is much preferable to placing them in the general rules, as thus they are readily found in conncetion with the subject to which they apply. The time of the examina. tion in each Class is also placed at its head. though sometimes they are all published on one sleet as a program.

The Departments are numbered consecutively, tirst, second, third. di., as may be desired; though sometimee the Departments are not numbered, the classes being lettred or numbered consecutively throughout, or num. bered with reference to the books into which the items are to be entered. 
SEc. 41. Numberng Premiums.-In order to faciltate making entries see Sec.60) a number should he given $t_{0}$ each item of the premium list. These are called premium numbers, and may run consecutively throughout each Class or each Department. The following will illustrate:

Prem. Nos.

i. Stallion, 4 years old and over.

2. Stallion, 3 year's old.

3. Stallion, 2 year's old, etc.

The method of numbering by classes is preferable, as by $i_{t}$ the needless practice of repeating the items of a class to form another, when both are the same, can be avoided. In such cases all that is necessary is to make the statement that its classification and premiums are the same as Class -, referring to the former one.

SEc. 42. Premium Ofĭermgs.-It is usual to ofier money as prizes, though diplomas and medals i.r some classes are quite common. Some societies have found it protitable to uffer certain artisles of silverware, de., agricultural journals and like things upon eertain classes.

Upon most items two or more premiums are offered, denominated first, second, \&c. To specify these it is customary to needlessly take a line for each, they being set fown, best so and so, second best, ditto, and so on. It ean all be expressed, and space and printing saved, and a neater looking page made, as follows.

1st. 2d.

1. Stallion, 4 years old and over....... \$10 $00 \quad \$ 50 \%$

SEc. 43. Sweenstakes Purses.-1n Live Stock Depart. ments, in adition to the general classes, classes denominated sweepstalies are made in which animals of different breeds, or of ditlerent ages of the same breed, are allowed to compete against each other for the purpose of ascertainung their comparative merits. 
Ssc. 44. Departmenis.-The subjects embraced in a Fair may be classitied under the general divisions, Domestic Animals, Industrial Arts, Fise Arts, and Agricultural and florticultural products. These are general an are usually divided into several more speeltic divisions, called Departments, thongh these general divisions ma be called Departments and the others classes.

Src. 45. Bowestic Animals,-The departments of this division are, Horse, Cattle, Sheep, Swine, and Poultry and Pei Stoch. Each will be aleseribed in turn.

SEc. 46. Horses.-This Department is variously classified, the only classes found common being Draft Horses, Poalsters, and Florses for General Use, or as they are Dftez called, General Purpose Horses. To these are added Thoroagbluseds, Light Barness Animals, Carriage and Coach Horses, Speed Horses, and sueb other classes as way be produced in the country were the Fair is located. Jacks aud Mrales are usually put into this Department.

In the gemeral classes a preminm is usmally offered upon Meares, greldings and stallions of each age to four years, and for those of four years and older. Alse, tuon brood Jimares and colts, and spans of mares aud geldiugs, three yoars old and four yeass old, thongh often these show withont regaral to ages. Sometimes in Draft Horses, mares and selitugs are male to compete with each other. Car. riage Horses are restricted to single animals and teams, without regarsi 50 aye, amb Coacb Horses to stalinons and teตmร.

In sweepstakes stallions are reguired to show a certain armber ar their colts of a given age, to test their breeding dualities. Freminns are also offered for displays of lorses and geldings, mares and natched teans of auy age or class.

SAC. 47. Cattle-This deparimert astally contains a chass for Durbam Herefords, Btrseys or Alderbeys, 
Holstens, Grades or Crosses, Fat Cattle, Milleh Cows, Oxen, Sweepstakes, and such other breeds as are raised where the Fair is to be held. The usual divisions ot these classes is for bulls, three years old and over, two years old, yearlings and calves; females, the same, except that four yearolds is added, and they are designated as heifers until thee years old. In grades it is common to offer no premium on bulls, the idea being not to encourage breeding anything but pure bloods. Fat cattle is divided for steers or oxen and for cows or heifers: and for oxen premiums are ofiered upon each age to four years old inclusive, and often for those that are nearest matehed or best broke.

In sweepstakes, bulls are required to show a certain number of their get of any or specified ages; and cows, a certain umber of their calves of required ages, and premiuns are offered upon Exhibitor's' herds, consisting of bull and four cows or heiters owned by exhibitor; Breeder's herds, consisting of bull and four eows or heiters bred and owned by exhibitors; displays of cattle and often pairs of calves, bill calves and heifer calves, and single bulls and cows of any age.

SEC. 48. Sheen.--Ifere two general classes are common, viz., Coarse or Long Wools and Fine Wools, the latter coinprehending Merinos and the former the different Wolds and bowns. To these are adred Grades. Fat Sheep and Sweepstakes. A better classification will be-Fine Wools or Merinos, Midrle Wools, to include Downs, and Coarse Wools, to include Lincolns, Leicesters and Cotswolds. Some prefer Merinos, Leicesters, Long Wools not Leicesters and and Downs. Where Grade Classes are male, it is usual to have at least two classes, Fine Wools and Coarse Wools.

Each class usually contains premiums for bucks and pens of three ewes, two years old and over, one year old, and lambs. In Grades, bucks are omitted. Fat sheep 
premums are upon three fat sheep and three fat lambs, and sweepstakes upon pens of ewes, and bucks to show lambs in each class, coarse, fine, or midale wool. Sometimes purses are added for lambs.

Sxc. 49. Swine.-The usual classitication is: Small Breeds-Berkshires, Yorkshires, Leicesters, suftolk, Essex and Short-Faced Lancashire; Larme Breeds-ChesterWhite, Poland-China, Mafree, Nomander, Byfield and jersey lieds, and sweepstakes. Other common ways are: harge Breeds, Berkshires and Small Breeds; Large Dark Breeds, Large White Breeds, Berkshires and small Breeds not Berkshires; ol, mstead of the last two, small Dark Breeds and Small White Breecis.

The usual premiums are upon boars and sows, one year old and over, six months old and under six monthsold; brood sows with tive or more pigs under six months old, and litter of pirs (tive or more) under six months old. sweepstakes include for each class a herd consisting of a boa: and four sows over six months old, owned hy exhibitor. hoars and sows any are, and often pigs under six months.

SEC. 50. Ponltry and Pet Stock.-This department inclurles chickens, ducks, geese, turkeys and other fowls; ferretts, rabbits, squirrels, birds, pigeons, fish, cetc.

SEc. 51. Industrual Arts.-A dificulty arises in making a proper classification of this division, and it has heen ustial eithes not to name the departments at all or call them Mechanies and Manufacturer's Products, and Textile Fabries and Domestic Manufactures. The dificulty with this elassification arises in the use of the word Janufactures, a term which may be used in place of l!ldustrial Arts, as it covers everything made hy art, hand or machinery, with other woris which it mcludes, to express but a part of itself, and then making other dopartments that come within its meaning as well, as does Me. chonies Produetions, Textrle Fabries, de. A strict classi- 
fieafion, howeyer, is not usually regarded as essentiai, all that is sought being to so arrange and express such prentimms that are offered that exbibitors may readily find them.

The ditheulty is greatly avoirled by classifying with reference to the place or manner they are made, rather than their character when made, ns Factory and shop Productions and Household Productions.

\section{SEC. 52. Factory and shop Productrons.-These} may be divided into classes for Machinery and Implements; IIousehold Furniture, Inplenents and Utensuls; Vehicles, Cabinet Wares, Cooperase and Carpentry, Leather Work, lmon Tork, Glass and Earthen Ware, Worked 3etals, Brass Work, Musical Fustruments, Merchants' Goods, Manutactured Preparations, Books and Paper, Mnler' Productions, and many others. Instead of Ifachinery and Implements, or as their subdivisions, classes may be had for Machinery Moved by Steam puwer, Machines and Inplements Moved by Horses, and Machmes and Lmplements IIoved by Hand; or Entrines, Shop Machinery, Agrienltural Machmes and Imple. ments, and Household Implenents and Ltensils. A very sonod classification for ordinary socteties is: Aqrientura! Machinery and inplenents. Ifowsehold Implements and Vtensils, and Hachinery and Implements for treneral use, the bater (onthprehending vehicles, hamess, boots and shoes, aud similar articles, whose use is not confined to cither farm nr torsahold. The ditherem chisses of these may be set off by sub-heads.

SEc. 5:). Lousehold Productrons.-These are divided somewhat with reference to therr nature, as into classes for I lain Teedle Work and Wearing; Ornamental Needle and Fancy Wolk; Fancy Domestic Ornaments, and Culnary Products. The first contains hed spreads, comforters, ruilts, mats and rugs, knitting, weaving, etc.; the second; applique work, bead work, caupas work, crocheting, is riding, embrodering, tating, treking, puffing, patch work, ete.; the third, wax work, teatber work, rustic 
work, hair work, and other articles of this class; the fourth, canned truits, preserves, pickles, Jellies, jams, catsup, bread, cake, ete. It is better to set out each of these in their proper class, having those of a kind grouped together and pointed out by a small sub-head, set in fulltace type, as they can thus be more readily distmguished and a repetition wili often be avolded; thus:

\section{Applique Work:}

1. Bracket Lambrequins.

2. Sofa Pillow, etc.

\section{Bead Work:}

3. Bead Basket.

4. 'Ioilet Cushion, etc.

\section{Embroidery:}

5. Chair C'ushions.

6. Foot Rest, etc.

Sxc. 54. Fine Arts. - It if not always easy to draw the line as to what should come in this department. Fine Arts usually represent ideas and Mechanical Arts purposes. The rule that such things as gratify the asthetical sense are Fine Arts, and such as have a practical use are Mechanical Arts, is a little more moderate, but still difficuli to apply. Paintings. engraving, scnlpture and architecture are acknowledged Fine Arts, but there can be no objection to classing with them many other works that are closely allied to them, such as decorated wares, €te.

Sec. 55. Agricultural and Horticultural Products.These are divided into classes tor Grain, Grasses, Vegetables, Fruits and Flowers and Plants, the latter beng often divided for professionals and amateurs.

Field Crops also come under this head.

Skc. 56. Discretionary Department.-A department is often adcled for articles which are not enumerated in the list, called Discretionary, as the payment of premiums 
upon such of these articies as are recommended as being worthy by the Awarding Committees is usually at the option of the Society and the amount fixed by the Board, with regard to the finanewal suecess of the Fair. Such a department is often a source of great perplexity to a Snciety, as often persons will take advantage of it by changIng the name of some article they may have, and thus ge: it entered in the department where they will be sure of a premium, in order to avold competition in the class where it properly belongs. When such a department 1 provided committees should be thoroughly instructed to watch and, if possible, detect such frauds. 


\section{CHAPTER VII.}

\section{ATTRAC'TIONS.}

SEC. 57. Success of Fars.-To make a jair a suceess two things are necessary - an exhibition and an attendance. The two, however, are elosely allied, so that when the former is secureal the latter is aimost certuinly assured. A Fair for but one day camnot be made protitable. and as people ean ordinarily attend and go through the exhibits in a day or less, and not eare to return to see them again the next, it is neeessary to devise something to inerease the attractions and excite such an interest that people will wand to attend every day while it lasts-as it is usually expressed, "something that will draw." Various measures hare been tried for the purpose. Places fir) resting comtortaby, with music from a good band te anliven the oreasion, add $(0)$ its pleasure, and the latter is especially moiting to some people. A list of attractions will be found in the following:

SEc. 5\%. Truals of speed.--One of the most extensive as well as most profitable inventions to atrat risitors to a Fair is contests, exhibiting she speed of horses, both summing, trotting and paeing. Two or three raves in which the horses are classed aceording to certain rates of speed are given each day. Often, to court breeders. raees between certain stallions in which farmers aud 
funciers are nuterested, and colt races of certain get, are mille up. Sometmes races between horses of local celebrity stir up ennsirlerable enthusiasm. Double team races aie also interesting.

Sec. 59. Other Equestrian Contests.-Nany doubt the vropriety as well as the morality of speed contests at Fairs, and in many instances attempte have been made to droud griving speed the preference over other desirable traits in a lorse, and to lead to greater care and effort to improve some of the other qualities of this noble animal. To take the place of racing they have invented contests hetween Draft Horses. Fast Wa!king Horses, Well Broken Ilorses, Graceful and Easy Riding Horses, etc. Besides these there maly be mentioned what is known as a Gentreman's lioad-horse kace and Mule liaces, hoth of which are ustually interesting and excitug. The former is a race hetween horses whcl have never been driven in a race ani which are untrained, driven by their owners three miles, the tirst being walked, the second under the saddle and the third trotted to a road wagon or buggy, the cwners heing required to change harness without assistance, except to hold the horse.

Two kinds of Mrie liaces, slow and fist, have been adopted. In the former the riders are changed, so that no person rides his own animal, and the purse is given to the liast one in. The exploits of riders to overcome the wellknown aversion a mule has to being ridden fast, often make these races a very comical spectacle.

Horseback lliding, by (xents and Ladies, and Lady Driv. ing are anusements that are attrative and pleasing to an atuience.

Piding contests between gịls under 16 and boys of like ages are also attractive. In these enntests the premium should he awarded to the best and most graceful rider.

SEC. 60. Agricultural Contests.-There is a class of contests tending to stimulate honest rivalry amnng farm iaborers that should be encouraged, and premiums for 
these come within the legitimate purposes of Fairs. Inw to excel in grooming a loorse, harnessing a team; in plowing and mowing; m cradling, binding, shocking and stacking grain; in chopping. sawing and splitting wood; in husking corn, building fence, layng tile, etc.. are surely important accomplushments to this class or people. and the well known conceit that many of them have ought to make such contests well patronized. Plowing Matches, Husking and Wheat Hiading contests have bet-n tried by many societies with good success.

SEC. 61. Athletic Contests and Sports-oceasions are often given for young men to display their strencth, actrity and skill in athletic sports and contests. P'rizes are often given for walking, ruming, jumping, wresting, tossing the cafrer, sledge throwing, putting the shot, tur of war, etc. Contests between Ilook and Ladder Cons. panies, Fire Companies, Inse Companies, etc., often draw large crowds. The rules governing these may be foumd in any work devoted to such sports.

SEC. 62. Miscellaneous Atractions.-At some Fairs a premum is oflered for young ladies who can get up the best meal of rictuals in the shortest time. We sugrsest that a cook who can gret up a wholesome bresilist, promptly, on time every moming, deserves the most hand. some of medals, and that the art ought to be encouraged. Butter making and other similiar contests might also be suggested. Band contests have proven attractive and profitable, as they save the employment of music on the day on which they take place.

Baby shows, with premiums for the most handsome, most intelligent, the leanest and tattest baby, and prem. iums for the oldest perzons in attendance are often given.

Sometimes a Pioneer Department, where premiums are oflered for ancient, curious and treasured al ticles of skill and handicraft, ancient household furniture, kitchen utensils, implements of husbandry or warfare, foreign and domestic curosities, ete., and an Educational Department where premiums are oflered for the most ap- 
proved comrses of study, plans of instruetion, examination papers of ptzpils, essays on different topies, drawine, penmanship, and work in other branches; school furniture and apparatus, books, maps, globes, charts, etc., are considered attractions and are added.

Special premiums are sometimes ofiered tor essays upon practical subjects connected with farming, as man. agng farms, plauting eeruin crops, road making, ete.

Where rats and other pests are numerous, to encourage their exterminatıon, a premium is often given to the distri॰t that sball sill the greatest number within a certain time; the tails of the rats or some similar part of other animals being required to be put win in bundes for exhibition and for evidence for makng toe award. The officers of a Society will often be able to add other attractions which the tine an direumstanees of thex Fair wil? suggest. 
CIAPTER IX.

GENERAL MANAGEMFNT.

SEc. 63. Audopron of Plans.- Tpon the management or a $F^{\prime}$ air its success more or less depends. To secrre frompt and harmonious action. it is essentual that some ime previons to its commeneement those baring its management showla lay out plans for conducting it, and as is approaches take weasures to hate them farried nut, by selecting the vecessary offeers and agenta, and instructing them as to how they should act. So far as these plans affect exbibitors, they should be jrinted as rules and regulations in the premium list for their enlightenment. In this chapter we shall discuss sucb plans as pertain to the private afiars of the society, leaving tbose of a general or publis nature for the nest chaptes, though some of the lntter are treated ineidestally sereis. 
Src. 64. Otficers and Committees.-Some Societies have a General Superintendent, to whom is assigned the management of the Fair, but more often the President, assisted by the Vice President, has its supervision intrusted to him. To avoid confusion and secure general harmony and good order, each emplnye should be instructed precisely as to what labor he is to perform. Each oflicer should be supplied with a badgé, so that he may be readily identitied.

In crder to secure proper management, each department is put in charge of one or more persons called superintendents or Managers. Sometimes these positions are parcelled out among the members of the Buard of Directors, who are designated as Attending Members. They should be men of good judgment and who will treat exbibitors horestly, impartrally and conrteously, as the best interests of the Society always require. To deeide upon the relative meris of the ditterent exhibits is usually left to a committee of three persons, called the Awarding Committee.

\section{SEC. 65. Selection of Superintendents and Com-}

mittees.-In well regklated societies, in order to secure competent, impartial and disinterested persons, the selection of A warding Committees and superintendents is left t) the Committee on Awards (Sec. 29;), which makes arrangements to have the nembers on hand when they are to be needer. The superintendents are sometimes called upon to sugrest names of persons for the enmmittees in their departments. and often have the choosing of them. Sume Societies wait and select them during the Farr from those in attendance; but this is an inferior method, as it is sometimes impossible at sueh trmes to obtain satisfactory committees. Care sbould be exercised to obtan persons having gualifications which tit them to act in the class where they are assigned. Filling of vacancies in committees is uslablly left to the superintendent or Commatee on Awards, which is in session upon the grounds during the Fair for the purpose. Com- 
mittees often receive pay tor their time, anc? qenerally are supolied wich their dimner by the society, as a ecmpllment for their labor.

Sxc. 66. Admssion of the Public.-One of the first things to be developed will be the method of admitting the public to the Exhibjtion. It is usually done with tickets, each party entering being required to provide himselt with one betore so doing. They are gene:ally of two kinds, one for a single admission, which is taken wp as the party enters, and the other a season ticket, which canmot be taken up, as the holler is allowed to pass out and in upon $1 t$.

The Secretary usually sells the exhibitor's and season tickets, though often it is done by the Treasurer. Parties are employed for the purpose of selling tickets at the gates, grand stand and other places refuning it. Fnough tickets shoufl he provided before the Fair to last through it, and be put $u_{p}$ in packages of one hmoled each. Some jerson slould be appomten to feliver tichets to the sellers each day and refuired to keep an aceount of them. Tickets numberea consecutrely, like railroal tickets, are becoming very common, as they are very valuable in ascertaining at any time just bow many have been sola. Each ticket agent should act independently of the others and be reruired to account in the return of tickets and monev for all the tickets that have been delivered to him. 'The membership and conpon tichets may be numbered and delivered likewise. At the wates partres are employed to take tickets and provided with larte tin hoxes in which to leposut them. They should be locked securely, having o.ly an opening to put the tickets into them, so that they ana not be prened antil the elose of the Far, when the tickets shoulu be connted, with a riew of comparing thein number with the nnmber repnrted as being sola. Sometimes turnstiles are used, provued with registering machines, 8 tbat no mistake ean be mate or traud perpetrated on the society. Each mght, when the gates close, tre flay's recipts shmuld be tmued orer to the proper 
officer and an account made of the same. When the soriety does mot provide a place for depositug ticket boxes, efc., (and it may he weil in any case) it is usual to leave them in the custody of the parties having them until the close of the Fait.

The gates sbould be npened as early in the morning as parties will want to hegin to pass out and in. The first thing usually necessary to he done is to have the police rraverse the grounds and ascertain who among those present are entitled to remain. Those not having tickets should be seut to the office to procure them, and tickets where found shoul! he taken up and returned to the proper officers. Police should not be allowed to talie money from parties.

SEC. 67. Ticket Frauds.-How to construct and manipulate tickets so to avoid being detranded by having then used hy difterent persous, or too often by the same person, has been a matter of considerabie study to the managers of rifterent societies. With single tickets that are taken up at the gate no such trouble exists; but when a party is allowed to retain his ticket it is readily aceomplished, by passing the ticket throun the fence, or sending it out by a messenger to some frend, who takes it and enters upon it, the gate-keeper in a rusin not always being able to observe the deception. To avosd this, some societres require the gate-keeper to punch such tickets whenever they are used, it baing an ohject of suspicion if the holes in one become numerous. Some limit the number of admissions to two each day, issuing a ticket with conpons, one of which is torn off upon each admission; or what is known as atcommutation ticket, having a number to be punched out upon each admission. A plan regarded better than enther is to issue a ticket having a coupon for each day to be torn oft when a person first enters; when he passes out let him show his ticket and get a sheck; then when he returus requure him to show the ticket again and take up the check. As the party who passes his ticket out secretly gets no check, no other per- 
son can enter in upon it. When a ticket admits man and wife, either may pass out with the ticket, or both tocether when two checks are issued, the parties heing required to return together-the checks never heing taken without the tickets. The entpons torn ofi will serve foi checks, and to he distinguished readny may be of a different color for each day.

When day amission tickets are used the same plan as to passes will work admirahly. The tickets for each day should be of a different color, and likewise wherever passea are used they should be of a duferent color for each dia, or possess such marks as will readily distinguish them. For ordinary admissions a ticket is issued and taken up at the gate and put into a hox provicied for the purpose by the gate-ieeper. Natrekets except these are usually transferable. These instructions will apply to srand stands and other places where tickets are sold.

SEC. 68 . Amission of IItpers.-How to regulate the acimission of nelpers and grooms of live stock has heen rather a vexatious question, aud a source of much tomble, as they are usually a lot of miscreants ready to take adrantage of every opportunity that is presented to heat the society, and sometimes the number that an exhibitor may want (often to get his trends admitted in that way) is out of proportion to what he really may need. some socseties charge for them at a full o: Imited price and others admit them free. Sometimes the number is controlled by the stock an exhibitor has, beng one tor a certain number of head. To avoid the difliculty arising from persons who get on the grounds and remain over night, claiming to be helpers for certain parties, some sucieties take the names of all assistants, and require the exhibitor to call at a certain hour each day and nbtain tickets allowing them to remain upon the grounds the next day, which unless they have in the morning when the authorities clear the grounds they are put off or required to pay. A more smple manner of arriving at the object is had in the use of a ticket having a coupon for each day, 
waich is torn off at the gate or by parties clearing the grounds. As these are usually sold at a leduced price, they do not allow the holder to pass the gate.

SEC. 69. Entries.-The work of makng entries is usually under the ebarge of the Secretary, who either attends tr it himselt or assigns it to certain of his assistants. Making an entry consists in recording the name of the exhibitor, a description of his exhibit and the class where it is to eompete, and issuing a tag to be attached to it, showng where it has been entered. Tine record is required to show who are entitled to compete, and the tags th assist the Examining Committee in finding the articles they desire. For making these entries the Secretary must provide plans and books properly ruled to carry them out. For tags a common shipping tag is used. No part of the labor connected with a Fair is more important than this, and perhays none of it has been conducted more unsatis. factorily. When the number of entries is large, to take them rapidly, as is often necessary, and have them aceurate is no easv task, as exbibitors do not fancy being required to wait to make their entries, aud in a hurry and confusion innumerable mistakes, leading to irritation and disappointment, one of which may possibly mar the success of the Fair, are liable to creep in and are often discovered co late as to be irreparable. Whatever plan that may be adopted should be so brief as to take the least possible time in making an entry, and so simple that in its use scarcely a possibility of maknng a mistake will exist.

SEC. 70. Plans of Hakng Entries.-Of these there are several in use. Often an ordinary blank book is used, in which the name of each exhibitor and a list of his exhibits are set dow in regular order one after the other as parties appear, the items being numbered consecutively from the first, each entry being designated on the entry tag and in the committee book by the number it bears, the latter being made by going through the list and collecting the items entered in each class and placing them in a book 
by themselves. The dithoulty with this plath, hesides heing latorious and slow, is that the promiscuous arrange-

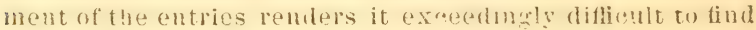
als that may be desired, and errors are likely to occur in

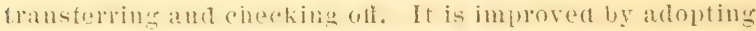

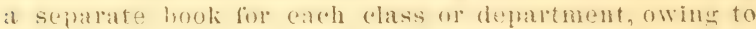
then size, the entries boing mumbered consecutively in

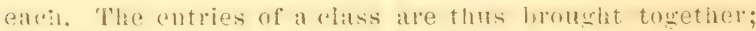
hut muless divisions are mille by setolug a certain page or

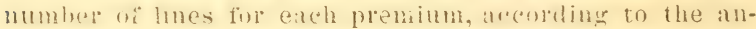
ticipated mmmber of entaies tor it, sin that those for each preminm mas he put together, the elassification will be inconplute. If this is fome, howevole the increased labo!

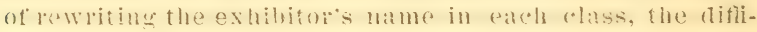
culty of turning the leaves to find what is wanter, the hindrance that will arise in findiug the proper book, especially it it hecome misplaced, atsl the dolay often ('allsed by some othry fersoms hat iug a bonk in use whem watnterl are quile serious. Then lun!ess it is thought dirsirable to wive these bouks, containime the names of ex-

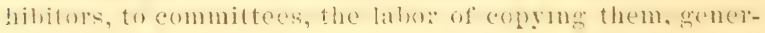
ally the last duty of the Secretary, to be performed at

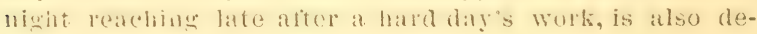
cidedly distasteful, to say the least.

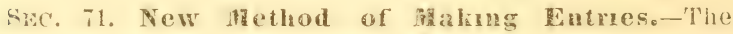
athther of this work has a phat of making entries that hats boen used and examined by many competent judges, and promonncer mogualled, in its simplicity, systematic arrangermont, and the raphoity and ease with which entries may he taken hy it. The basis of the system is to arom repetitun, so that when an exhibntor's nume has been once recorded, instead of rewritum it for every diflerent entry or class of entries he may make, the one will suffice for all, and when the description of anything bas been written in entering it once, it need not again be written for all the entries that may be made of the same thing. Whether by the sime person or different persons. And even more, the method being such that the printed matter in the premium list may be used and the books 
prepared at leisure of the secretary before the Fair, so that the nimes of the articles need not be written at all, the arrangement heing so simple and systematic that the whole can be put mto a bonk containing hut few leaves, and any ciesired part or premium turned to at a glance. As the usual ratio of the number of entries made to the number of exhibitors is about ten to one-that is, on the arerage each makes ten entries, and if mon the whole there should he five entries for each premium ofiered it will he seen readiiy that snch ampthod will save ninetenths of the lahor otherwise required in writing names and four-lifths of that required In writing the description of the entries. Deseriptive circulars will be sent upon aplication. See advertisement on last page of cover.

\section{SEC. 72. Nom-enumpraced Articles.-A (lepartment} is usually made for such articles (see sec. 56 ), and it is usual to enter them all together in one bonk. The difliculty in this lies in their examination, as special committees for the purpose must be chosen and the members changed often on account of the difherent classes of artjcles to be judged, often causing considerable trouble and expense. By our plan we avoid this by leaving lines after each class for writing the names of such articles as are entered of the same charceter, so that they will all appear together and be acted uyon by the regular committee.

SEC. 73. Entry Tags.-Fnr each entry a tag is issued and upon it usually there is written a deseription of the thing to which it is to be attached, the number of the entry corresponding to the number in the entry book, and the department and class $m$ which it is entered. Another quite simple plan is only to place upon the card the department and class where it belongs, leaving the exhibitor to attach it properiy. It has the ohjections, however. (except in live stock and other, departments where tho art. icles of a kind can all be grouped together so as to be readily discerned) that it will often be diflicult to find what is wanted when the awards are to be made, and also that the names of exhibitors will be required by the com. 
mittee. A netter plan is to place upon the entry tac the entry number, the department, class and the premium number as tound in the list (see sec. 41), using it for a deseription often containing several words. Indeed, all that is necessary to use is the entry number, the committee judging from the looks of the thing whether it is being examined under the proper chass, as in the second method above, and in such departments as the exhibiter is required to be by to show his things one tag will do for all. It is usually better, however, to add the department and class.

To avord getting property mixed a method of having an entry tag aivided into parts, pertorated between them so that the lower part may be torn ofl. making a detachable check, and requiring it to be presented (it being a duphcate of the other part) to the supermtendent of the Department at the close of the Fair in order to obtain property, is in use at some of the largest Fairs. Two tags are sometimes used tor the purpose, one to be attached to the exhibit and the other retamed to identify the property.

Sec. 74. Making Entries. - In this a drision of labol will be found very protitable. Let a definite portion of the work be assigned to each employe, one to keep the entry books, one to make the tags, and so on. Have the party who keeps the books and the one who makes the tags sit close enough together to communicate readily, and as the exhibito: announces his entry, the one record it and announce its number and the other place them on the tag. Where the entries are made upon blanks, they shou!d be first passed to the bookkeeper and the number of each noted and then passed to the tag-maker. The work is thus systematized. Each person soon becomes familiar with his work, and mistakes are less liable to occur than otherwise.

Skc. 75. Committee Books.-In order to place before the committees the iuformation as to what entries have been made, and for them to report the results of their ac- 
lion, it is usual to prepare for them a small lunk, containinc a list of entries, with proper space for them report. several methods are in use, depending upon the method of reconding the entries. The author bas visited one n? two Societies where the secretary gave the committees the book in blank, expectimer then to gopre about and find what has been entered, examine them and report, but it is not thought that that practuce is very extensive. It is tasual to crive with each entry its number. so that the con:mittees may know what mumbers to look for upon the targs, and when all the entries have been found. To colleces these when the entries have heen made and set down in order as parties lave come in, requires considerable labor, but the convenience arsing to the committee in baving them all together, and the liability to omit entrits that is thus avoided wall outweimh 1t. Sometimes the namo of the exhibrtor is griven also: but it is rot necessaly and it is renerally thought to be woug, as committees will act moge jumbartially withont them!. When separate entry books are usco, and the entries classified when made, as described in Sec. - the entry hoolis are often given to the committees to save copying. To avoid griving the names of exhbitors to commutees a plan is m use, in which the leaves of the book are cut apart between tlae names and items, and the part containing the names sewed up so that they cannot be seen.

By the author's pian a separate trook, similar to the entry bonk, except smaller, with space for remarks, is provided for each class and prepared smilar to the ent?y book at the leisure of the secretary before the Fair. Thea after the entries close a few minutes' work will transfer tue unmbers appearing in the entry column of the entry hook into the respective committee books, where they will appear in compact furm in then appropriate places ready for use. This will be found a decided improvement over the old and usual method, which requires the Secretars to labor until midnight and after, in preparing his committee books, after a hard day's work in making entries. The committee first ascertain the where- 
abouts of the exhibits, hearing on the tags the numbers fonud an the entry columms, and when they make the the award, place the entry number leceiving the first yrentium in the column for awarts beacied first; that reeetring second in the eoluma so headed, and so on, so that a mistaise can hardly oceur.

Srec. 76. Wental Proweges.-The matter of let?ing out the rights of sellmogr artioles mon the froumds is one of a fonsiderable ineome to sucieties, and the practice is raried as much as any branch of the business. Some selt the whole business to one farty, leaving him to sublet it as he ehooses. Others sell exelusise mivileges on certain things, and whers make no distinction, selling anything that a person may want, whthout regard to what bas alreaily been sold. Whe particular comrse to be adoptec mast be lett to each society to delermine for itself, as it mast wreably depend mon tue extent and character of their exbibituon. In ordinary socictiss, a kiming hall, a vold lumeh stand and confectionery, peanut, poplecorn, lemsnade, iee eream, sola water, hot candy, and beer stands often are let. The letring is cone privately, by senied bids, or at auction sone tmo previbus to the Fair.

The dimang ball oecmpant bas the sole privilege of selling warm meals; the cold luneh stand is confined to eold eat Bibes; the otber stanis sell what their names indicate, often exclusive, anc often bave in aldibson lemonale, eukes, gingerbread, Aruits, sandwikhes, eigars and to. baeco, pretcels, bologna, dried beet and hread, or some of them.

At the Far it is astal to have applications from medieine men, fakers, hawkers and pedulers without limit.

The charaeter of the stand usually regtalates its price, though in some places it depends largely unon the promjupnee of its location and extent of the ground oceupied, as so much per toot front on a certain thoroughfare. Payment is sometimes required in advance, and some- 
tumes part in adrance and a certain portion of the balance each day. The former way is preferable as it does away with the labor of going around tu collect during the Fatr.

The lettung of stands is often given to a commitee on tiat subject, which determales what shands shall be let and upon the conditions, puts their disposa? into the hands of some competent person. Blank contracts, eonfoluing terms of letting, tume of payment, etc., should be nereared, so that the questions that arise witu a class of stand men ustally known as "kickers" nay be aroided.

It is usla where the ermund is not let fy the foot to provide that parties shall he conined ro such locaton as may be riven fimm, and that no person wall he allowed more that one place of selling. I'eanut and pop-corn yendors nften have prirlece of perdingr. Crand stand prrvileges are reserved to parties purchasing them.

Sometimes it is provided that no wheels of fortune, prize packuges, gambling devices, etc., ur intoxicating liguns will ',e allowed upon the grounds, and that parties who violate tireir contricts will forfert their privileges and the sums prid upon them. So also that ro aliowances or deduction will be made on account of luad weatuer, poos attendance, or other cause.

\section{SEC. \%. Rental Prisleges, Contuned-Admis*} siows.-The question of admuting persons securing privileges and their assistants is sometimes a serous one, on accoun of their well kuown disposition to impose upon the society when an occasion arises. Some Socielies give a season ticket with each privilege, and such a number of additional tickets as ther judgment dictates as being proper. Others make the amount paid the price of the privilege alone, and charge extra for admissions the same as to orlmary visitors. Uthers issue a certain per cent. of the price of the privilege in tickets at a certain price, as ten per cent. of the cost at 25 cents each, leaving the party to dispose of what he may not need and to purchase more 
should he not have enough. Sometmes wagons furnishing supplies for stands are allowed to go in tree ot charge. and often they are required to lay them in before a certain hour in the morning, after which they are charged as other persons.

Sxc. 7s. Poldce.-To preserve order and protect the property of exhibitors although it is uslat to provide that the society will not be responsible for any loss that may necur), it is llsual to employ an imple police force, and have them stationed about the grounds where they may le neeted. A chief of Poliee is apponted, to whom in. structions as to what is needed are siven, and he may be held responsible for thrir beng carried out. 'Two sets of men should be employed, one for day and one for night.

Swo, 79. Marshals.-In order to give notices, make ('alls and announcements. and assist in conductung the eeremonies and carying out the ofheial program, an olicer designated a Marshal is appointed, who usually has one or more assistants to aid him. In order that they may go about readily they are asually on horse back. In some Societies the othee is elective. The Marshal often wears a red searf as an insigna or his oflice, and his assistants often wear blue ones.

swc. s.). supplyug Forage.-As it is uswal for societies to tarnish hay for feerling and straw for bedding anmals upon exhibution, it will be necessary to adopt somie method of supplying them. Too often it is hauled and stacked mon the sonuds, where parties withont distinction are allowed to go to it and take wbat is wanted. A luttle system here will prove a saving to the Society. When no builaings inare been provided to put it in, it should be stacked outside the grounds. Each night a wagon should be sent to the place where it is kept and loaded, and enough loft at each stall for use during the following day. This will save its being picked over and tramped upon and wasted at the stack. Some Societies limit the quantity of hay allowed to each person, as follows: 'To each head of cattle, ?lolib.; to each horse, 15 lbs.; to each sheep, 3 lins. Fhe stalls may be filied with straw irotitably from the loads when they are first hauled. 


\section{CHAPTER X.}

\section{RUIES AND REGUIATIONS.}

SHe. Ni. Bivasions.-The rulcs and recrulation'; relate ine th the combluet of a Fitir are diviled iato two classes.

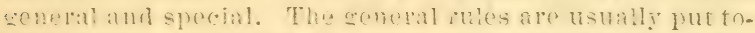
wather mati the front of the catalog: while the sperial

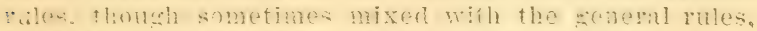

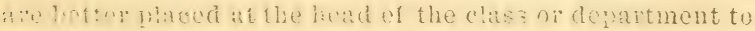
which they relate.

\section{GENERAL RLLES.}

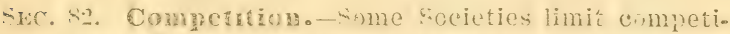

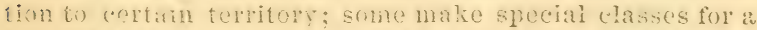
limilen territury, and som!e a!l but eertan speciat clases. it 15 usual. however, to open competition to all, as it brings otut a latuer exhihition an? increases the attractiveness of the Fair. Oftenthe live stock elasses, or a pnrtion or them, are contine? to parties who have bred the stock, in order to encourage rreeding and avoid show stock; and articles are required to be entered by or for the manufacturer or contriver, or by some meinber of his 


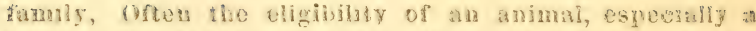
lwore, is limited to one class. Sonne allow one to be en. rered in as dany elasses tis the osiner desires, hut sanw wa once. Forne datye no restrielbus, while some allow one to Do shown ja as unary elasses as the omuter desires, but

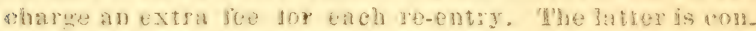
siderea a very good war, as it loes away witls the segrew

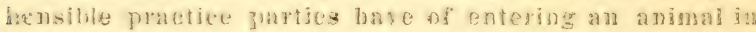

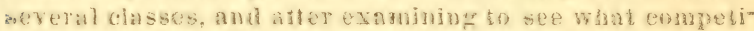
tson there wall be in rach, showing lim ansly where it is

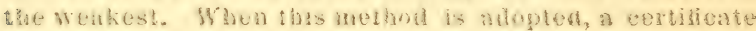

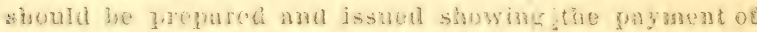
the extra entry fre, and the sane required to be shawa do the superintement of comathe bute late examination is made, in oreler that they reny know that the sumal as eluklue in the particular vlask. Otherwise the Sociedy

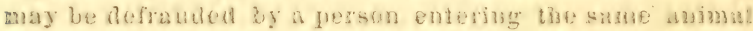
twice, under a grettace that ta kas two. The certiticast ram be on the entry tag.

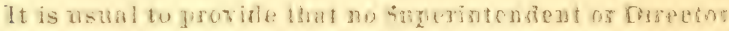

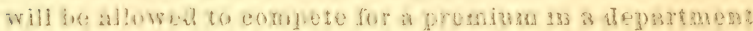
over which he has edarge.

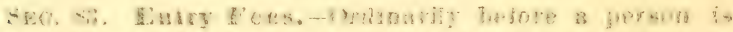

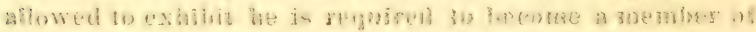
the suciery (See. T) or to pay an enstry pee. Wh ben the

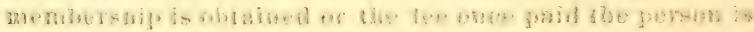

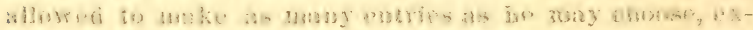

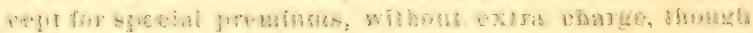

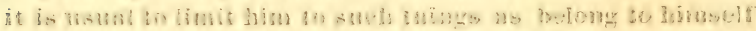

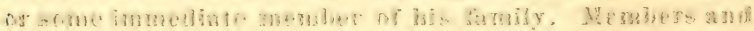

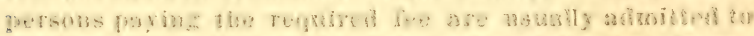

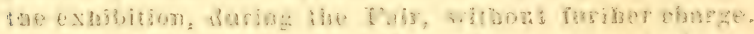

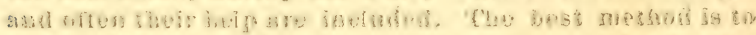

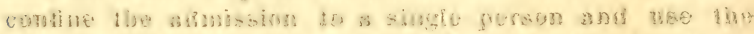

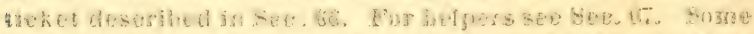

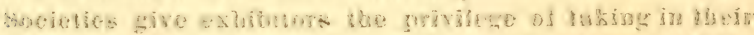

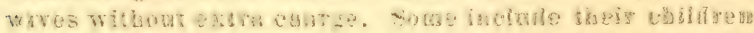

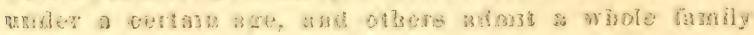

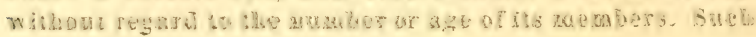


a wholesale admittance is nut ouly a deerled abuse, but is danerous to a society and usually the means ofextensive frauls beiug pricliced upon it. It may swell an attend. ance, hat it will deplete the treasury. Fandies are unusually labe at such tmos, and it is a knowu faet that men otherw serewaded as honest will often in such cases mincle the members of other fatmilies with theit own, or 1 : their wife happens to be away. ot has already heen admitcal, so that the opportunity oceuts, they whll take therr neightors wife and palm her ofi as their own. It is

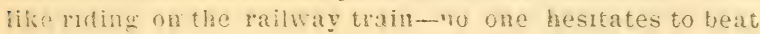
the conductor.

To secure thiformity, some tociefies issue a ticket to the exhimton and in adition swe hum a certain number of frenerally form) admission tickets. Lut the ohject is illy secured by this metluch. as the mumber is often in excess of what are wanted, and they are sold, so bhat individuals derive the benefit instead of che Society.

Gome sorieties as an mdreoment charge exhibitors no entry tee, hut requne ol those desiring to sec the exhibition the same almission as other visitors at the gates. The matter of furnishing them tickets, spolien of m the next sectunn, hy the metuods now in use. is so much involyed that this practice is becoming quite customary, and it worles well. though perhaph it may be improverd by reyHurlue exhibitor's ot live stock and such others as remain "1)(1) the grounds at night to purchase season tichets.

Some societies charge for admissions and require an entry fee of a certain sum or a cortain per cent. of the purse or first premium of the purse to he paid. An entry tec of ten per cent. of the purse is common in speed Classes. In sweepstalies it is usual to charge an extria fee, and often to aroid heing obliged tu give the premum to some fornidable animal without competition and at a small expense to this owner, it is requiled that in such classes there shall be a certain number of entries in each purse. 


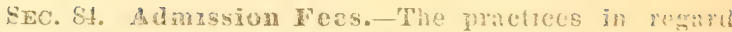
10 admissions are as various as ibere are diferebl fir cieties. Orlinary visutors are usually charged by the day or smople at?mission. Sometimes sonson tickets are sotat to parties dosiring llum. Somelmes parties are allowed ix drive mpon the grounds thes of charye, and otten admission fees are charged for vehiches-so much for, a surzle

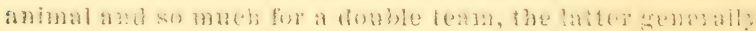
beings about double lhe former. Seats ju the grand stamb are usually ex: a.

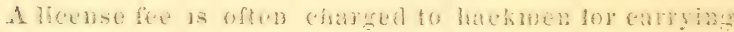
passengers, especially when they are aliowed to drue

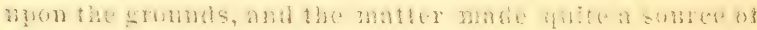
protit.

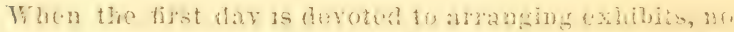
a dmission fee is charged for that tay.

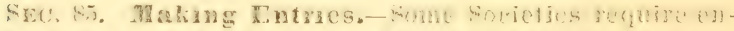

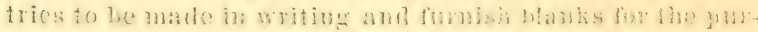

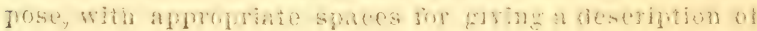

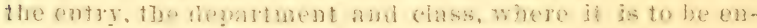
tered, and the xame and address of the exisititor. 'rhis melhnd will he fomnd vainable in searching out the respousmbility for mustakes bhat ocern in entries. sach as makjng them in the wrong chass are the like. It is asmal

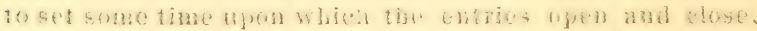
and it will be fomma a freat lavor to bave the lime for

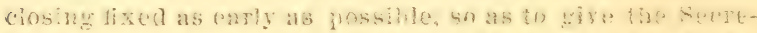

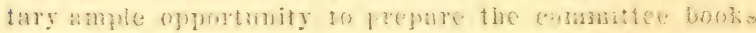
before the examinations are to begin.

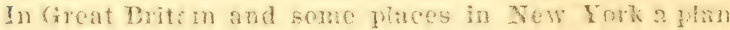
las been adouted of baving the entrias chsed, in sone instances as eariy as thirty days before the enenine of the Fair, and publishing a catalog of the same, wha the postoflice atdress of the exhibiton. TVhen the exhibition

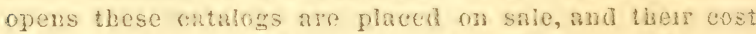
oflen more than paid by the queejpts. Yisitons with canalog in hand, where the exiblitis are gavious, cun thus 


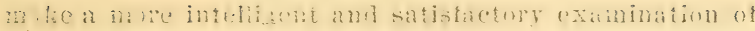
them. It is nsual a devote the first day to making en-

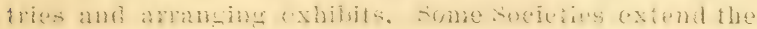
time until nom the seeoud day, but this is a mistake, as it will be formd mile mure satisfinctory to efose them on the

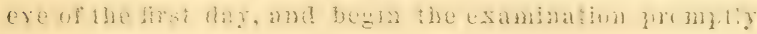
on the second fity.

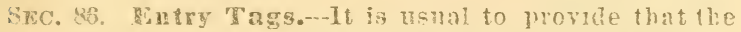
entry tags must he securely attached to the exhibit or sept so that they maly be shown to the aymmitee lipen the examination.

Shes 7. 6hangug Entries. - In orter to do away the enntemulble practice some exhibitors have of making there entrits, and after ther bial what obposition they will bave to encounter, seeting. upon some pretext, to get them elangen into a elass where it will he less fomidable: an chance of entry should be allowed after it bas been once made, unless to correct errors, ana then not unless the error is decidedy apparent.

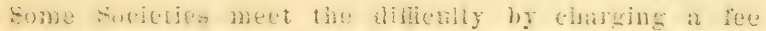
for changing entries. In orter to servinize the whieve che may bave in whing to range an entry, and that

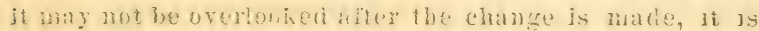

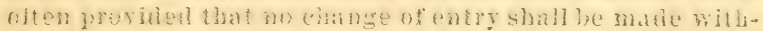
fout the consent of the superintendents, both in charge of the thentunent where the eatry bas been mate and where it is to he changed to. When an eryor is discoreded, if tine commilice books bave heen mate mo, the change should be carlet into the proper ane at once, so that it will not be missed upon examination.

SEC. 85. siecreey of Entries. It is tsual to proviac that in nu case will the owner's name be given or any per. son be allowel to see the entries until after the awaris Inve been made. The reason for this is obrious.

SEc. 89, Erhizits. Proper space and aceommodations are provided by the soneties for exmbitors. Sometimes dissatisfaction grows ont of locations, especially of stalls, 
but this is digicult to avoid. Some charge for sinare and fix the prie aceorring to location. Othere make no assigmment until after the entries are opened, and then having the stalls fombered, assign them conscentively in the oreter in which they are received. This often secures promplues in makinge cutries, and the assignment can be fhen made intelligently. Besires it lats the advantawes of

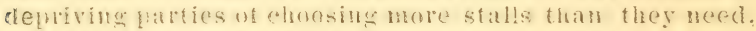
it thrning out, when the exhluitom opens, that the soriety has stake to spare, for the strpused want of which other yarles bave beenturned away. It is always provided iluat exhibutis shall be upon the srounds by a certain time (usually hefore the Fair npens for visiturs). and shall not he removed hefore its close without the consent of the superintendent of the departuent where it halongs, or some ntherspecitied ofticer. This, like ofluer similar rules, is diticult to enforce: all that can wsually be dose beiner to attheh as a penalty the forfeiture ot any premiums that have been awarded to the exhihuthe. "ene enforecunent of the rule however, is highly impriant, as otherwise the attractiveness of tho Far moht he greatly lessened near its elose. It is ustual to provide that no ohnoxious or renulsive articles will be received npon the grounds, and if entered without being known will he removed at once.

Exc. 89. Stabling and Forage. It is usual to fumish f xhibitors of live stock with stabling and hay and straw, dorme their stay upon the grounds, fiee of charge, and provide gram upon the gromals to be sold at cost. Sumetimes a chatre is made for stalls and pens, and quite often 10r box-stalls. Exhibitors are required to attend to the care and keeping of their property. To protect themselves nom imposition by those who enter animals for the sake of getting them fed during the Farr, the society genprally proyides that for all animals entered for compatitio.s and not exhibited, a charge (generally so muen per day), will be made for stalls and keeping.

SEC.90. Supcrutendents. Notice is generally given that superintendents of departments will he in attend- 
anee at a certain time one or nore days before the farr, in receive property to be placed upon exhibition. It is mate their dutg to recerve all proferty entered for exhibition; see that it is placed and aranged in a suitab!e abs attractive matmer, and that the tars are properly and securely attathed. They are given the entive elates of the poperty uren exhibition in thes respective departments. and refulled to see that the same is properly proteoted and eared fiss, Tbey are nsually requiral to be present and take cbarge of the exminations, direct the teommitferes, and assist them m their babors. 'They should be firmilia with the suxiety rules so as to dispuse of promuldy any questions that may arise.

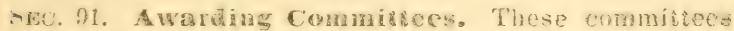
are usmally defined and llue manuer of their seleotion given, so that exulbitors may feel that they wall be harly mad impartially dealt witl. The menabers are ureed to attemo z)romplly at the time they are wanted, and at is osten

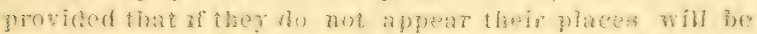

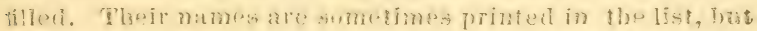

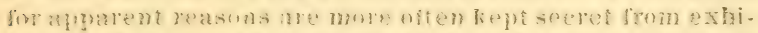

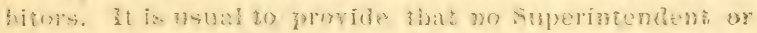
perion reluted to any competitor will be albured th aed as a member of an kwarling Committee.

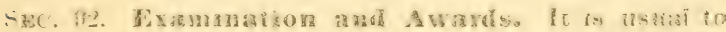

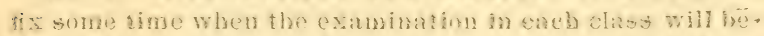

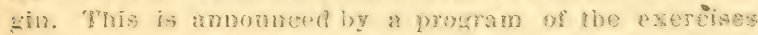
jronted in some gart of the eatalier or at ihe head of the vlass. Witla tire examination of live stress if is fulite in

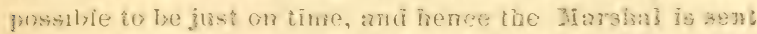
around where the animals wanted are statiobed, to an nource the elasses publicly as eacis is reary, so bat tirose

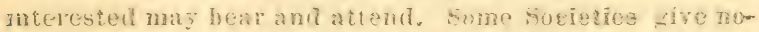

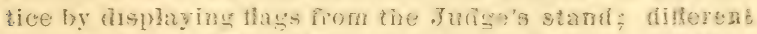

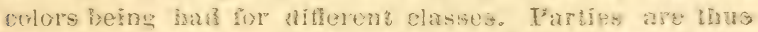
given a eerianil number of nintues to aprear. The exam inations sbouhl fogin as early as possible 30 ais to asoid interference by the orow of spertators, sn wew Kor is 


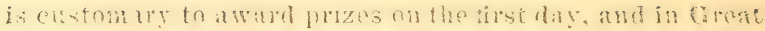

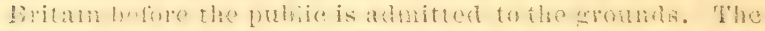

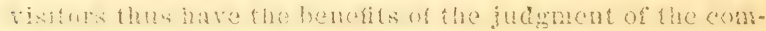
mitteo in making their comparisons.

When the time arrires the commitee bonks finould be delivered to the superintendent of one of the mombers, who shombl be thoromghly instructed how to keep it, and report the awards, so that no mistakes may he made. This makes somoboly responsible for the report, and is

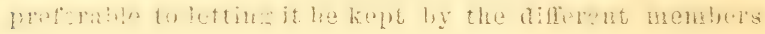
as it happens.

When the exammation berins, for cach article, the party lnaving the book should call orer the entries that are shown to have been made, examise the tags, see if tiacio numbers correspond with those in the imotis, and if all are present. Tom moh care cannot he exereised in making these oxaminations, and any carelessness or nerlect that may take place, although the Society may not be to blame therefor, is apt to be charged upon them. A very grond method of making awards is as follows: Cast the first vote by ballot witiout previus consultation. It a matjority of the rotes do not agree, conpure views as to the relative merits of the exhibits without expressing incividual preferences, and ballot again. If an agrecment is not then reached, app:y to the Superintendent and bave another person adided to the commuttee. Then contine the awrol to nne of the exhihits reegiving ballots from the oricinal committee and ballot acain. It is important to aroid restrunt, that the commitice be by themselves as much as possible durung their deluberutions, and hence if is eustomary to provide that no person will be allowed in

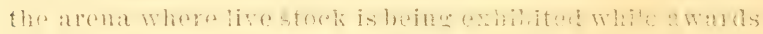
are being made. Wben an agreement is reached, in order to record it, the Superintendent or other party harmg the hok in ehargo should he notibed. This he mat (a) by

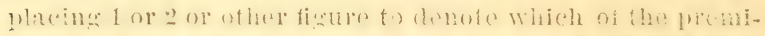
noms have been wiren opmosite the artictes to which they are awarter!. In some societies committeos are remired to give reasons for their awards. 
In the committee books used in the author's glan of making entries, a colamu is provided to mat cach premiam in, and it is destgnated by placing in the proner column the number of the exhibitor ohtainiag the premtum. as found upon the entry tag. These books serve gor any

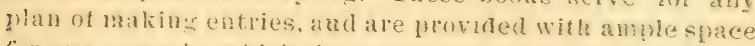
fur any remarks which the commottee may desire to make. When any question arises it shutid be referred to the supermfendent, who, if the cannot explain at, should ohtain the desired information and ustrect the commites hefore they are allowed to proceed. Should any errot be fornd it shocikt also he repurted, so that it can be corrected in timu to atond trouble if possible. If any entry is not tound it should also be noted.

It is ustal to provide that no arard will be marle to any animal or article which is not decidedly meritorious, and when on! cre entry has been male for a premium it will be awarded first or second, as it may deserve; also trat iu alisplays the quality of the exhihit will take precedence over quantity.

When discretionery preminms are given the committee should be instructed to recommend only such as are worthy of a prenium. Committees are also instructed to gerquire froot upon any disputed point arising before them, suck as uwnership, age of animals, and the like.

When the awards are finshed the committee should sign their namcs to the list, so that they may be kept for information that may be desired relative to any award.

SEC. 93. False Entries, Interference with Commit rees, Etc. For self-protection and that the committee may be unmolested, it is usual to provide that if any false entry is made, or auy disrespect is shown to any award or the $A$ warding Committee by any exhbitor or his agent, the shall forfeit all the awards made to him, and the superintendent shall give notice of the same in his report. Also that no person will be allowed to interfere with the com. mittee during their adjudications, and any person who in 


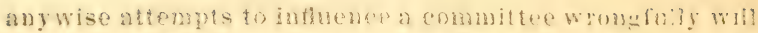

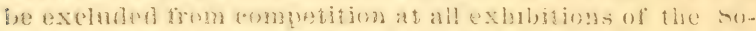

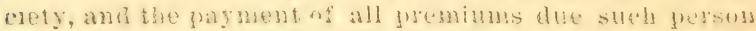
will be withbeld.

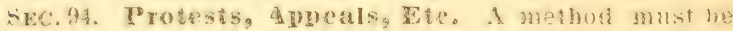

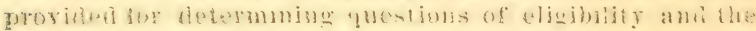
likethat Decus. It is often provided that questions of

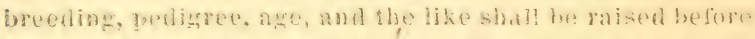

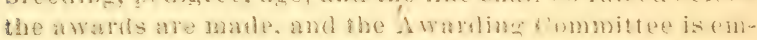

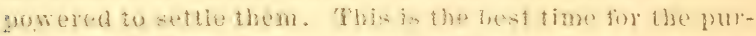

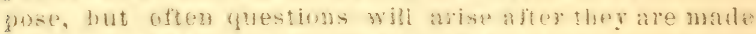

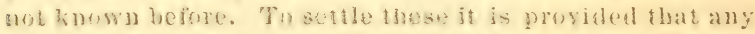

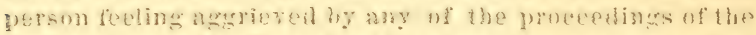
touciely during the thar shombe submit the watter to the

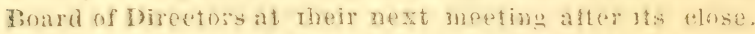

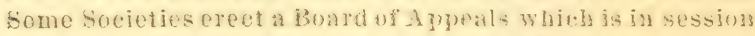
auring the Fair to settle questions that arise.

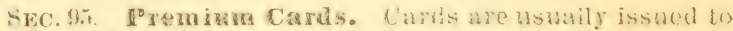

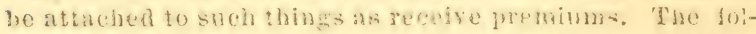
Jowing evlors ale asually thusen to designate the disterent

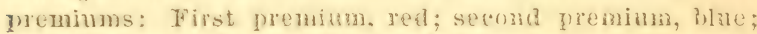
inird preminm, varions eoluss, foibsums of like colors are

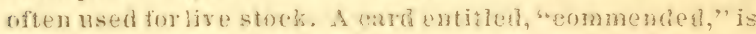
also prepared to be attactued to sach non-enumerated arij-

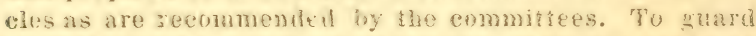

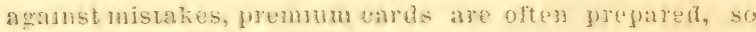

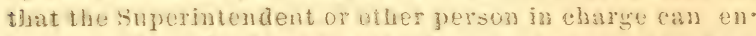
ter upon them the fepantment, elass, ane enty 10 which the award is made and sion the sume. Partues are ther required topresent the card to nbrain their premium mum. ey. When the eard is gresented, if it arrees with the committee's report no mastake exists; Dtherwhe the eards go only to point out where awaris have been made, and are of no value alter the Tair except as finepsakes. In sucis cases the commuttee's rogort is relied upon to deternine to whom the premium shoula be paich.

SEC. 36, Paying Premeums. In order to sllow the Secretary to make out a list of the anards and enable the 
Bitatitumeet and aispose of any gluestims that maty arige Orlative to them, it is ustral fo provide that the premmung will mot he pad tutil some time after the bair. It is quite

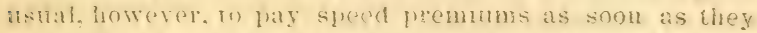

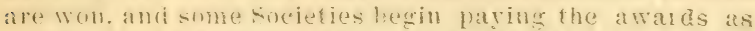

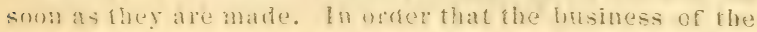

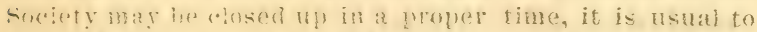

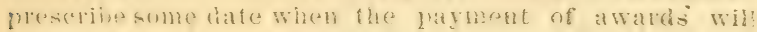

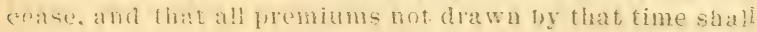
he forferted and revert to the Society.

It is alstomaly to provide that the premitum awarted

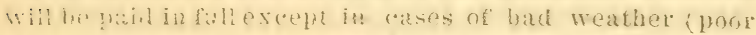
atrendance sometimes added; the recents should be inadegnate. Whas they will wo paid pro rata. sometmes it

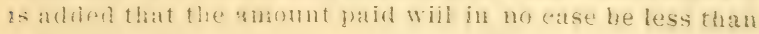
a certain per cent. of the simount oflered. It is a grood flan to have the time when premums will hro pard printed

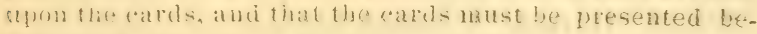
fore the money can be drawn if such be the case.

sacictitestor their ow! protection gererally reserve the ri-lit of withdrawne any fremium or withbolding its paymont in case the awarl has heen obtained by frand or (1the: inproper means, and tor such callses as they may may deem just.

\section{SPECIAL RULES.}

The special rules pertaming to a Fais, although they mal he witu the others are, as has already been mentioned, more properly sivea in connection with the particular alass to which they helong. The most general of them wil: be found in the following:

Sycc. 9. Domestre Animals. Inder this head rules rovering the following should be placed. No award will be made to any breeding animal that may be barren, or having any unsomulness, except that such unsoundness in breeding animals will only be regulated as is considered transmissible. Some require all breeding animals to have been brea within two years, and all unsound animals are often exciucied. 
In blooded closses, purity orhood, symmetry, size. eanty toaturitz, and chberal charactevistics of libe several hresds

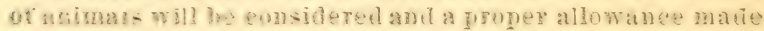

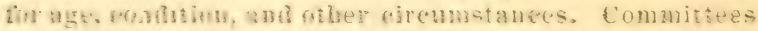
are verecially required unt to eucumrage vyerferi animals.

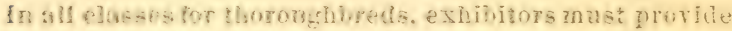

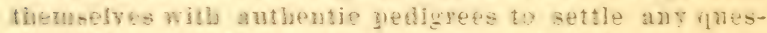

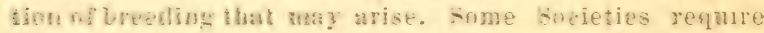
exhibitors th de?ser a pediged on the serretury when the cotries are mate. and home retuire kuplicates. so as to bave ore fis tillog and she chber fur the romuittee.

Xoprowinn will be awarded wher the animal has heen fatted for the batwer, the onjerts being to compure merits for breeding purpuses.

Bec, as. Forses. In combetzon with there tories we

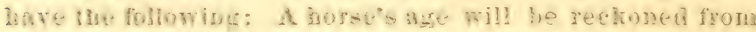
the lst day uf dancury of the yese in whied he was fualed.

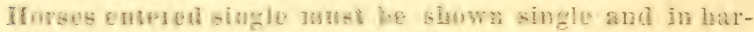
news, except otallions and anianolo three years old and somenger.

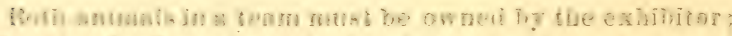

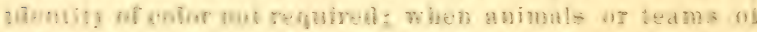

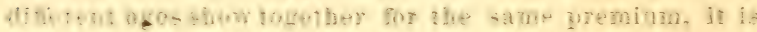

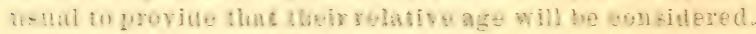

The rutes by w biek dasess are sestricted from thowing

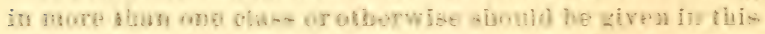

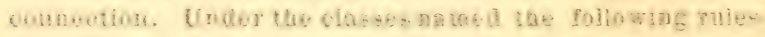
should be placed.

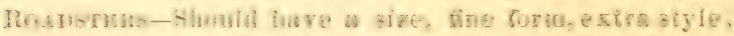
and action and marks of endarance.

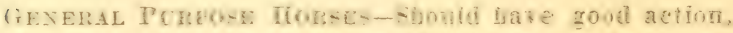
wall, size and style, and be asefal for heswy draft garposes. 
Drafr Irofses-chou!d liave extra muscilar developmont, grool size and style, a good walk, aud be useful for beavy draft purposes.

CARRIARE IIORSFA- - Chould he good size and in reams, be woll matrhed 13 size, color, style, temper amd acton. sometimes the animals complising a team are allowed to be of a difierent sex.

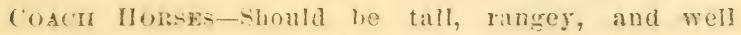
formed, and possess good style and action.

IN SPEED CIASSES-The amount of the entry fee, the mumiser of entries and starters refuired, the hour at which the horses will be called, the manner the racing will be condueted, as aecording to the rules and regulations of the Sational Trotting Association, and other essentials should be given.

SEC. M?. Catte. Mere the following rules may be given:

FOR GRADES-No thnoughbreds cun compete as grades.

Fat Catre-Are varionsly judged, and no general rule ran he given. Fome alt) as a standard that all other

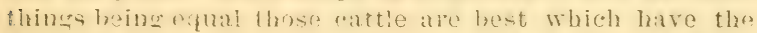
freatrot weight in the smallest superfices. Animals are often required to he wowised mun the grounds, and exhibitors required to furnish at statement or the eost and manner of therr feeding.

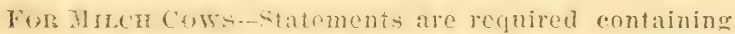
the ace and hreed of the (e)iv, the trme of her ealving, and the fuantity of milk il wewht and pounds of butter made during ten days between cortain dates previous to the Fair attested hy afidarit. This statement is required to be returned with the repn't of the commitiee, and no preminm awarded without it. Snmetimes it is only required that the cow be millied in the presence of the committce.

For Oxwa-They are refuired to be shown in the yoie and well broken and handy, 
Fon Swmpstakn-Sometimes it is provided that anymils exhibited in either the exhibitor's or breeder's herd cannot he shown in the wher.

SEc. 10\%. sheep. All sheep of sidhicient age, shorn the past seasun, must nave bren ciosely clipper, not earlier than April. Exhibitors are required to turnish the enmmittee a certifiate of the time and manner of shearing, and also a certiticate showing the age of lambs. Sometimes rans two rears old and over are judred by their get. of wheh at least two of each sex are required on exhibi140n. Sometmes a rule is aclupted requiring (yutity and quantity of Wool, and perfection of form anul size to be especially eonsidered.

sec. 101. Fonlty. When preminms are oflered upon “Fow!s and Chickis," the temus arousually defined "Fow!." heille a hird hatched prior to the real of the exhibition. and "Chick," one atring the same year. Often such it nicety is not desirable, hut whenexactness ris required the judges are to he governed! I) $\mathrm{y}$ the American standard of Ex. cellence, a first preminu ind being required to score a certain ammber of points. eimhty-five or ninely, a second a (eertain number, and so on. Entries are usually requred in pairs.

- Suc, 10\%. Industrial Arts. Except in displays and merchints' goods articles competing tor premiums must be entered fin or by the malier, improver, or crintriver. sometimes the rule is made to apply to all articles the

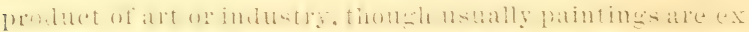

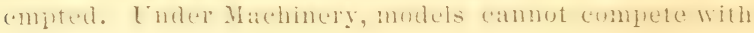
full size machines.

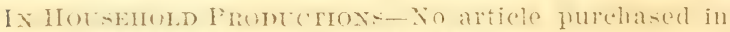
a store, make in a diatory. or ont of the fanty of the exhi. bitor, is allowed to compete, and sometimes they are limited to those manufartured whthin the gear of the firar.

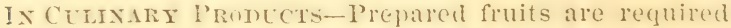
to haye hesu put up ing the exhlbitor for actual use during the season of the Fair. 
SEC: 14\%. Agrichlture and in this depatment are usually required to have been pro-

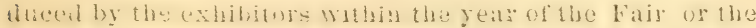
one previous.

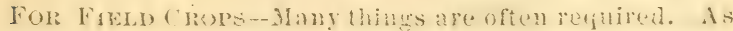

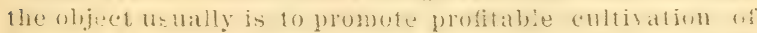
the soil, atatements as to the masisurement of the land hy

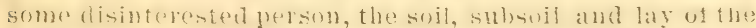
land, and its smromblingrs, what he previous crop were,

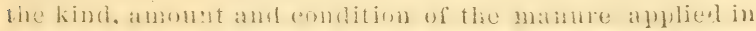
rationg the refor), the flepth and time and mannel of plowing. tmse and manney of sowing seod, its weight. quallty,

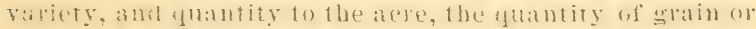

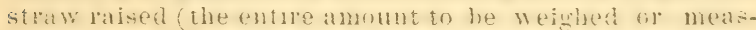

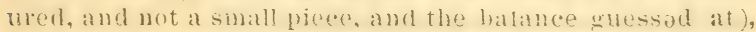
and the whole eost in money, labor and materials in producing tlite cron), are to be furnished attested by attidarit.

For buren-statements are required firmo the num-

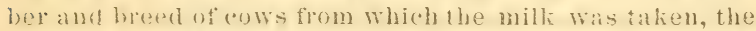
number wimilings, whether any food besides grass was used. Hhe foeatment of the milk, the method of cinturnge

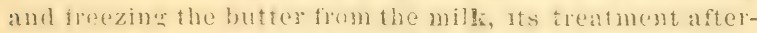
wath. the guantity and kimb of silt used, and whether saltpetre, sulati, or other sulsstances have becil emploged in making or coloring.

Fon CHEks-In adrition to the alove, whether croam bas beon msed and how extensively, the methed of preser $x$ ins and preparing the remet and such other matters as informution may be desired upon.

Frurs-Are required to be a celtain number of each varuty, upon plates furnished hy the exhibitor, and each variety distiuctly labelled.

SEC. 104. Fine Arts. Sometimes exhibits in this department are required to be entered by the maker, thougls Societies in order to obtain a good áisplay of paintings and pictures, confine the rule to others lhan display, or do not apply it all. 
Sice. 10\%. Flonal. Flowers and Plants are ustally required to be exhibited in the pots where grown.

Sac. 106. Dascretionary Department. Fol this a rule Iike the following will often be a saving to the society. "It is intended to enumerate in the premium list all artictes that are thought destrable tor exhibition. Howerer such non-enumerated articles as parties bave, may be entererl in this dentrtinent, and if decicedly meritorions the comnitfere will recommend them for a premium." sometimes it is left for the colnmiftee to defermine tho anount to he pat upon these articeles, hat it is thought arbisatste to ard a stipulation like lice followng: "I is determining the amount to be pard upon commended articles, the Board will take mto consideration the amount oflered won like articles, their similarity to aricles mentioned in tire list, and the financial suecess of the Fir.", 


\section{CHAY'TEI XI.}

\section{ACCOUNTS, REPOR'TS, ELC.}

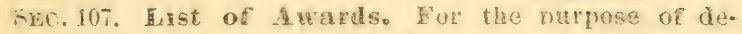
efrnining who aro entilled to the resportive preminms and aseertaining the anownt requifed to lay thems, it is Isual to brepare a list of the suceessful extibitort and sher awals. This list is made lip trom the conmatee re. ports either with respeet to the rassisicatiou of the gua. miums or the namesol exhisitors under taeiv initial let-

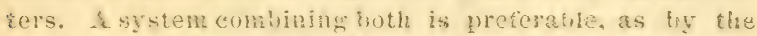
former to vinom any particular award was made and the

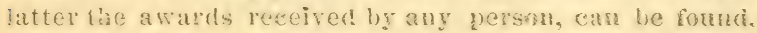
hoth of which is often rexessary. The hooks of the author's plan are thus provided and so arranged that the list is made In in the tirst instance, saring the labor ot making this list. 'Whe systcus of mumbertur premiums has at alvatage here also, as in making up the list by classes the preminm mumbers can de used fos the premiums they designate, and much writing saver.

SEc. 10s. Ireeping Accounts. The watter of keeping accounts wall come more properly in a treatise on book-keeping, and we stall not enter into it greatly. Thereare two plans of conducting the tuancial dewartments of a Fall, viz: to make it the dity of the secretary to receive all moneys of the society, ketping a proper ac. connt thereof, and pay the same over to the Treasurer, and to kave the money paid directly to the Treasurer. he keeping the required aceonnts. We can see no especial objections to either of the plans, though the former is reregarded with preference, as the Secretary then has a rea. 
nod of the repipts bentherwise would not. In order bo be aeeorate a eash book slondd be kopt, and all moneys enlezer jutn it just as regeised. 'To make the reports they may be eatered in fowds aceording to the source from which they were received, as admission tees, exhibitors lickets, stands and pripileges, swrepstakes entres, etr., or the somree simply designated, and the acerant asterward jourmalized.

A stevk book will be neeessary m socieiles haring a cazpotal sinets, in record the payments of stockholders. their alrialends, ete. All jayments of money should be apon nriers arawn by the seretary (ofien requnded to bo signed by the I'resilent), and showing for what they are arawn, moraer to enable the ereasurer to enter them is bis aeeonats properiy. The oriers should be provided with stubs, showing what they are issued for and with reeejuts to be signed by the parties who receive then. sometimes, for the payment of preninms. a list is ruade out mpon a blank similas to an ordinary pay roll, having spaces for the name of the exlsibitur, the awasd, its amount, aud fus the signitme of the party receising the pay. This is gren to the Treasurer, who pays accord. ingly. The seeretary sisonld also keep an aceount of the orders given, aceorling to the funds upou which they are drawn, as Polive, Jiseellanenus, Eimployes, Printung and Aasertisum. Preparing Gromas, J'emiums, -upplics, de. so tlat ke can makc an intelligeut report therefrom.

S5: Bot. Aumual IReports. When the doings of the Sodery close amunally, it is usual to prepare a report giviag the tinancial doings durimg the fiseal year then expirsor, to be read at the stochlolders meeting and often permied. In this report the receints and expenditures sitsouta be elassibien accoraing to then nature, as is suggestet in beegmg the accounts, ss it will be interesting to rav in detsil wat las been done. If the Secretary first receives the Soriety's money, be should make the report, asd the Treasurer only reguired to report to twe Board, so this Mis account rasy be compared with the Secretary's. (b) herw ise the Treasurer will malse the report. 








$$
70^{\circ}
$$




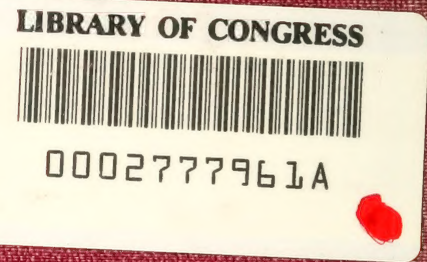

